\title{
Re-description of Strandesia sanoamuangae Savatenalinton \& Martens, 2010 and description of a new species of Strandesia (Crustacea, Ostracoda) from Grande Terre, New Caledonia
}

\author{
Amanor KISSEIH ${ }^{1}$, Janet HIGUTI ${ }^{2}$, \& Koen MARTENS ${ }^{3,4 *}$ \\ ${ }^{1}$ P. O. Box OS 2213, Accra, Ghana. \\ ${ }^{2}$ State University of Maringá (UEM), Centre of Research in Limnology, Ichthyology and Aquaculture \\ (Nupélia), Graduate Programme in Ecology of Inland Water Ecosystems (PEA), Av. Colombo, 5790, \\ CEP 87020-900, Maringá, PR, Brazil. \\ ${ }^{3}$ Royal Belgian Institute of Natural Sciences (RBINS) Vautierstraat 29, 1000 Brussels, Belgium. \\ ${ }^{4}$ Department of Biology, University of Ghent, K.L. Ledeganckstraat 35, 9000 Ghent, Belgium. \\ ${ }^{1}$ E-mail: a.kisseih@outlook.com \\ 22E-mail: janethiguti@gmail.com \\ *Corresponding author: kmartens@naturalsciences.be \\ ${ }^{1}$ urn:1sid:zoobank.org:author:FEE8A50B-A44E-4131-8827-808F03659762 \\ ${ }^{2}$ urn:lsid:zoobank.org:author:3A5CEE33-280B-4312-BF6B-50287397A6F8 \\ ${ }^{3}$ urn:1sid:zoobank.org:author:9272757B-A9E5-4C94-B28D-F5EFF32AADC7
}

\begin{abstract}
The New Caledonian Archipelago is a hot spot for biodiversity and endemism. Whereas popular groups such as birds and plants are well-studied, invertebrate groups such as ostracods remain ill-known. Here, we re-describe Strandesia sanoamuangae Savatenalinton \& Martens, 2010, originally described from Thailand ( $8000 \mathrm{~km}$ away from New Caledonia), and describe Strandesia mehesi sp. nov. Both species are known only from females. Material for the present study was collected from diverse aquatic non-marine habitats from Grande Terre, the main island of New Caledonia. Whereas S. sanoamuangae is seemingly easily identifiable, $S$. mehesi sp. nov. is part of the Strandesia vinceguerrae/vavrai species cluster in the genus, of which the 'older' species (described long ago) often have incomplete and superficial descriptions. Differentiation between the new species and the other members of this species cluster are based on small anatomical details of the valves. The current paper updates the known number of recent freshwater Ostracoda of New Caledonia from 14 to 16 species, although at least five of these species have an uncertain status.
\end{abstract}

Keywords. Morphology, taxonomy, Cyprididae, Cypricercinae

Kisseih A., Higuti J. \& Martens K. 2020. Re-description of Strandesia sanoamuangae Savatenalinton \& Martens, 2010 and description of a new species of Strandesia (Crustacea, Ostracoda) from Grande Terre, New Caledonia. European Journal of Taxonomy 627: 1-28. https://doi.org/10.5852/ejt.2020.627 


\section{Introduction}

The New Caledonian archipelago, situated in the Pacific Ocean, North East of Australia, and one of Earth's top 25 priority conservation regions (Myers et al. 2000), is known for its rich biodiversity and a high proportion of endemism in flora and fauna, which has attracted the attention of botanists, zoologists and biogeographers (Grandcolas 2017). The taxonomy and ecology of larger organisms, such as birds and plants, is relatively well known. Smaller organisms, such as ostracods, on the other hand, were largely overlooked in the past. Only 16 species of non-marine ostracods were thus far reported from this archipelago, including the two species reported on here (Table 1).

Ostracods, commonly known as seed or mussel shrimps, are bivalved microcrustaceans, consisting of an uncalcified body enclosed in a calcified carapace consisting of two valves, dorsally connected by a hinge. They are common inhabitants of many (semi-) aquatic environments, both marine and non-marine, and have also been sampled from subterranean environments (Danielopol et al. 2002; Martens \& Horne 2016). Owing to their calcified valves and carapaces, ostracods are also well represented in the fossil record (Boomer et al. 2003; Martens \& Horne 2009). Among the meiobenthic crustaceans, ostracods remain poorly studied, especially in the Pacific Oceanic Islands (Martens et al. 2008; Meisch et al. 2007, Schabetsberger et al. 2009). This situation exists despite the accessibility of ostracods and their potential use in the earth and environmental sciences as proxies of environmental health and change, both present and past (Boomer et al. 2003; Ruiz et al. 2013).

There are presently 2330 subjective species of living non-marine ostracods described in 270 genera (Meisch et al. 2019), but many living and fossil ostracod species, both marine and non-marine, remain undescribed today. There are three superfamilies of Recent non-marine Ostracoda: Cytheroidea, Cypridoidea and Darwinuloidea (Horne et al. 2002). Of the described non-marine species, more than half belong to the family Cyprididae. In the tropics, the Cypricercinae, characterized by a Triebel's Loop at the distal edge of the caudal ramus attachment, is one of the most common subfamilies (Savatenalinton \& Martens 2009). Savatenalinton \& Martens (2009) proposed three new genera: Bradleytriebella, Nealecypris and Pseudostrandesia as additions to the Cypricercinae and excluded Neocypridella Vávra, 1895, leaving Astenocypris Müller, 1912; Bradleycypris McKenzie, 1982; Bradleystrandesia Broodbakker, 1983; Cypricercus Sars, 1895; Diaphanocypris Würdig \& Pinto, 1990; Spirocypris Sharpe, 1903; Strandesia Stuhlmann, 1888 and Tanycypris Triebel, 1959 as valid genera in the subfamily. In addition, Ferreira et al. (2019) recently described a new genus in the Cypricercinae, Neostrandesia Ferreira et al., 2019, bringing the total to 12 genera. Strandesia remains the most speciose genus in the subfamily.

\section{Material and methods}

\section{Study area}

New Caledonia is an archipelago in the South West Pacific. It is located $1500 \mathrm{~km}$ to the north of New Zealand and $1500 \mathrm{~km}$ to the east of Australia. It comprises the main Island 'Grande Terre', the Loyalty Islands (Maré, Lifou, Tiga and Ouvéa) and other smaller Islands, such as Ile des Pins and Ile Belep. Grande Terre, from which the samples for the current study were obtained, represents the emergent parts of the Norfolk Ridge. New Caledonia lies just north of the Tropic of Capricorn between latitudes $18^{\circ}$ and $23^{\circ}$ south and longitudes $158^{\circ}$ and $172^{\circ}$ east (Rawling 2009). New Caledonia is part of the mostly submerged Zealandia continent which separated from Gondwana in the late Cretaceous. Grande Terre has thus been separated from Australia for ca 84 million years (Mortimer et al. 2016). In the Eocene, it accreted additional terranes (Grandcolas 2017). Due to New Caledonia's complex geologic history, there has been much debate about the origin of its biota. Vicariance, dispersal or both have been proposed (Grandcolas 2017). A recent meta-analysis by Nattier et al. (2017) suggests repeated colonization via dispersal. 
Table 1. Non-marine ostracod species known from New Caledonia (adapted from Martens et al. 2019). $(?)=$ uncertain species or identification.

\section{$\begin{array}{lll}\text { Species } & \text { Locality } & \text { Reference }\end{array}$}

\section{Darwinulidae}

Penthesilenula brasiliensis (Pinto \& Kotzian 1961) Hienghène, Mt. Panié Martens \& Rossetti 2002

Vestalenula marmonieri Rossetti \& Martens $1999 \quad$ River Diahot Ouegoa $\quad$ Rossetti \& Martens 1999

\section{Cytherideidae}

Cyprideis australiensis Hartmann, 1978

Grande Terre

Hoibian et al. 2000, 2002

(?) Cyprideis consobrina (Brady, 1890)

Noumea

Brady 1890

\section{Notodromadidae}

Kennethia major (Méhes, 1939)

Canala

De Deckker, 1979;

As Notodromas major Méhes, 1939

Maddocks 2007

\section{Cyprididae}

(?) Cyprinotus cingalensis Brady, 1886

Loyalty Isl., Ovéa

Neale 1979

\begin{tabular}{|c|c|c|}
\hline Cyprinotus drubea Martens et al., 2019 & Paita & Martens et al. 2019 \\
\hline Cypris granulata (Daday, 1910) & Paita & Martens et al. 2019 \\
\hline (?) Eucypris wolfhügeli Méhes, 1914 & Loyalty Isl., Ovéa & Méhes 1939 \\
\hline (?) Strandesia rouxi Méhes, 1939 & Koné, Canala, La Foa & Méhes 1939 \\
\hline $\begin{array}{l}\text { Strandesia sanoamuangae Savatenalinton \& } \\
\text { Martens, } 2010\end{array}$ & Grand Terre & This paper \\
\hline Strandesia mehesi sp. nov. & Grand Terre & This paper \\
\hline Candonocypris novaezelandiae (Baird, 1843) & La Foa & Martens et al. 2019 \\
\hline Syn. : Candonopsis (sic) caledonica & & Meisch et al. 2007 \\
\hline Syn. : Herpetocypris caledonica Méhes, 1939 & & Méhes 1939 \\
\hline Syn. : Candonocypris caledonica (Méhes, 1939) & & De Deckker 1981 \\
\hline $\begin{array}{l}\text { Syn. : Herpetocypris caledonica var. minor Méhes, } \\
1939\end{array}$ & & Méhes 1939 \\
\hline Stenocypris major (Baird, 1859) & Canala, Koné & Martens et al. 2019 \\
\hline As Stenocypris malcolmsoni Brady, 1886 & & Méhes 1939 \\
\hline Stenocypris marginata Daday, 1910 & Koné Canala, La Foa & Méhes 1939 \\
\hline Cypridopsis sarasini Méhes, 1939 & Loyalty Isl., Ovéa & Méhes 1939 \\
\hline
\end{tabular}


New Caledonia has an oceanic climate with annual mean temperatures varying from $21.9^{\circ} \mathrm{C}$ to $24.1{ }^{\circ} \mathrm{C}$. The highest temperatures occur at the beginning of the year. There are two main seasons: the hot season from mid-November to mid-April and the cool season from mid-May to mid-September. The short and main dry seasons occur between the hot and cool seasons (Beauvais et al. 2006). The surrounding ocean greatly regulates the temperatures of the islands (Harter et al. 2015) and may mitigate against the effects of global warming (Pouteau \& Birnbaum 2016).

A mountain range runs from the northwest to the southeast of Grande Terre and obstructs rain clouds moving west or southwest. Consequently, the west coast receives $1000 \mathrm{ml}$ of rain annually compared to $4000 \mathrm{ml}$ in the northeast (Rawling 2009). This mountain range has encouraged a dense river network but, in some cases, restricts the development of large rivers. Lentic systems including (temporary) marshland cover about 4000 ha of Grand Terre (Beauvais et al. 2006).

New Caledonia is renowned for its regional and (micro-) floral and faunal endemicity (Caesar et al. 2017) and has been designated a biodiversity hotspot (Myers et al. 2000). The archipelago also serves as home to some relict taxa (Murienne 2009).

\section{Field sampling}

Ostracods for the current study were sampled during three sampling trips to Grande Terre, New Caledonia between November 2016 and June 2018 by Janet Higuti and Koen Martens. For a description of the main aims of these expeditions, see Martens et al. (2019) and http://www.laplaneterevisitee.org/en. Sampling covered diverse aquatic habitats, including temporary pools, (artificial) lakes, ponds, streams and rivers with varying macrophyte diversities and densities. A total of 350 samples were collected from these habitats using a hand net with mesh size $160 \mu \mathrm{m}$. In addition, the coordinates of the sampling locations were recorded and environmental variables including water temperature, $\mathrm{pH}$, salinity and electrical conductivity were measured. A brief description of each station was noted, and photographs were taken.

\section{Laboratory processing, SEM imaging and illustration}

Samples were washed to remove large debris and excess sediment, and ostracods were sorted from part of the living samples under binocular microscopes using a glass pipette the same evening of sampling. The samples were then preserved in $97 \%$ ethanol in airtight plastic jars, labelled and transported to the Belgian laboratory in metal canisters. The separated ostracods were stored in plastic Eppendorf tubes in $97 \%$ molecular grade ethanol and duly labelled.

Selected specimens were separated into their soft parts and valves under the Leica dissecting microscope using fine entomological needles fitted in pencil holders. The valves were stored dry in micropaleontological slides with their convex sides up. The limbs of the soft parts were dissected from the body in glycerine and mounted on glass slides. The slides were thoroughly sealed with transparent nail polish.

Line drawings of the limbs were then made from the slides with the aid of a Leica compound microscope equipped with a camera lucida. Valves were also imaged and measured in various orientations and magnifications using a scanning electron microscope (Fei Qanta 200 ESEM, RBINS Brussels).

\section{Institutional abbreviations}

MNHN = Muséum national d'Histoire naturelle, Paris, France 


\section{Abbreviations used in text and figures}

Valves and carapace

$\mathrm{Cp} \quad=$ carapace

$\mathrm{CpD}=$ carapace dorsal view

$\mathrm{CpFr}=$ carapace frontal view

$\mathrm{CpLL}=$ carapace left lateral view

$\mathrm{CpRL}=$ carapace right lateral view

$\mathrm{CpV}=$ carapace ventral view

$\mathrm{L}=$ length

$\mathrm{LV}=$ left valve

$\mathrm{LVi}=$ left valve inner view

$\mathrm{RV}=$ right valve

$\mathrm{RVi}=$ right valve inner view

\section{Limbs}

$\mathrm{A} 1=$ antennula

$\mathrm{A} 2=$ antenna

$\mathrm{CR}=$ caudal ramus

$\mathrm{Md}=$ mandibula

Mx1 = maxillula

$\mathrm{T} 1=$ first thoracopod

$\mathrm{T} 2=$ second thoracopod

$\mathrm{T} 3=$ third thoracopod

\section{Attachment of the caudal ramus}

$\mathrm{db}=$ dorsal branch

$\mathrm{vb}=$ ventral branch

The nomenclature of the limb chaetotaxy follows Broodbakker \& Danielopol (1982), for the second antenna the revised model proposed by Martens (1987), and for the second and third thoracopods Meisch's nomenclature (2000). Higher taxonomy of the Ostracoda follows the synopsis by Horne et al. (2002).

\section{Results}

Class Ostracoda Latreille, 1806

Subclass Podocopa G.O. Sars, 1866

Order Podocopida G.O. Sars, 1866

Suborder Cypridocopina G.O. Sars, 1866

Superfamily Cypridoidea Baird, 1845

Family Cyprididae Baird, 1845

Subfamily Cypricercinae McKenzie, 1971

Genus Strandesia Stuhlmann, 1888

\section{Type species}

Strandesia mercatorum (Vavra, 1895).

\section{Diagnosis}

See Savatenalinton \& Martens (2009). 
Strandesia sanoamuangae Savatenalinton \& Martens, 2010

Figs 1-3

\section{Re-description}

Female

$\mathrm{Cp}$ in lateral views (Figs $1 \mathrm{~A}-\mathrm{B}$ ) subovate and dorsally arched with greatest height at about $2 / 5$ of total length; anterior and posterior margins rounded, posterior margin narrower. CpRL (Fig. 1B) with LV overlapping RV anteriorly, ventrally and posteriorly; overlap greatest antero-ventrally and anteriorly; periphery of LV visible dorsally. CpD (Fig. 1F) and CpV (Fig. 1E) sub-elliptical, with greatest height at mid length, sloping to blunt anterior and posterior extremities; LV with anterior extremity almost perpendicular to the anteroposterior axis. CpV (Fig. 1E) with LV margin sinuous with weak protrusion towards RV slightly posterior to greatest width. CpFr (Fig. 1H) not oblique, but with LV larger than $\mathrm{RV}$, ventrally enveloping the RV. Cp with surface ornamented with tiny tubercles, small pits and thickly rimmed pores with sensilla, the latter in lower density (Fig. 1G). Central area of Cp surface in ventral view and particularly on RV without tubercles; pores with sensilla not rimmed. Central area of LV surface in dorsal view without tubercles; pores with sensilla not rimmed. LVi (Fig. 1C) with calcified inner lamella wider anteriorly, an internal groove and an inner list present along valve margin. RVi (Fig. 1D) with calcified inner lamella wider anteriorly and without selvage or inner list.

A1 (Fig. 2A) with seven segments. All segments with apical setae. First segment with one short dorsal seta and two long ventro-apical setae. Wouter's Organ not observed. Second segment trapezoid-like with one short dorso-apical seta and one large (more than half the length of the segment) Rome Organ (R) at the ventral side. Third segment longest of all segments with two short apical setae, one dorsal and one ventral. Fourth segment with two long dorsal and two short ventral setae; one of the short setae approximately half as long as other. Fifth segment with three long dorsal and one short ventral seta. Sixth segment with four long apical setae. Seventh segment with one short aesthetasc (Ya), one short seta of equal length to Ya and two long setae.

A2 (Fig. 2B-C) biramous with two-segmented protopod, a reduced exopod and three endopodal segments. First protopodal segment with three short setae; one proximal and two unequal ventral setae. Second protopodal segment with one long seta. Exopod a small plate with one long seta and two very short but unequal setae. First endopodal segment with one ventral aesthetasc (bulbous but elongated), one long apical seta reaching beyond the last endopodal segment and six natatory setae (five long and one short); the long natatory setae extending beyond tips of apical claws. Second endopodal segment with two unequal dorsal setae; a group of four ventral setae (" $t$ "-setae), two long and two short; one short seta approximately equalling the length of the terminal segment; three serrated apical claws (G1, G2 and G3) and three apical setae (z1, z2 and z3). Terminal segment with two serrated claws, one long (GM) and one short (Gm); one aesthetasc fused over a short distance with an accompanying seta and one g-seta.

Md Palp (Fig. 2D-F) with four segments. First segment with four ventral setae; two long plumose setae, one long smooth seta and one short $\alpha$-seta; this segment also with a small respiratory plate (not shown). Second segment with four ventral setae (one stout hirsute $\beta$-seta about $2 / 3$ the length of $\alpha$-seta, three long hirsute setae and one short smooth seta) and three dorsal subapical setae (one long, one about $2 / 3$ the length of first and the shortest about $1 / 4$ of first). Third segment with six apical setae (one $\gamma$-seta hirsute at the distal half of its length, four longer smooth setae and one short seta about $2 / 3$ the length of the terminal segment) and four unequal dorsal subapical setae. Fourth segment (Fig. 2F) with three claws and three setae apically, claws longer than setae. 


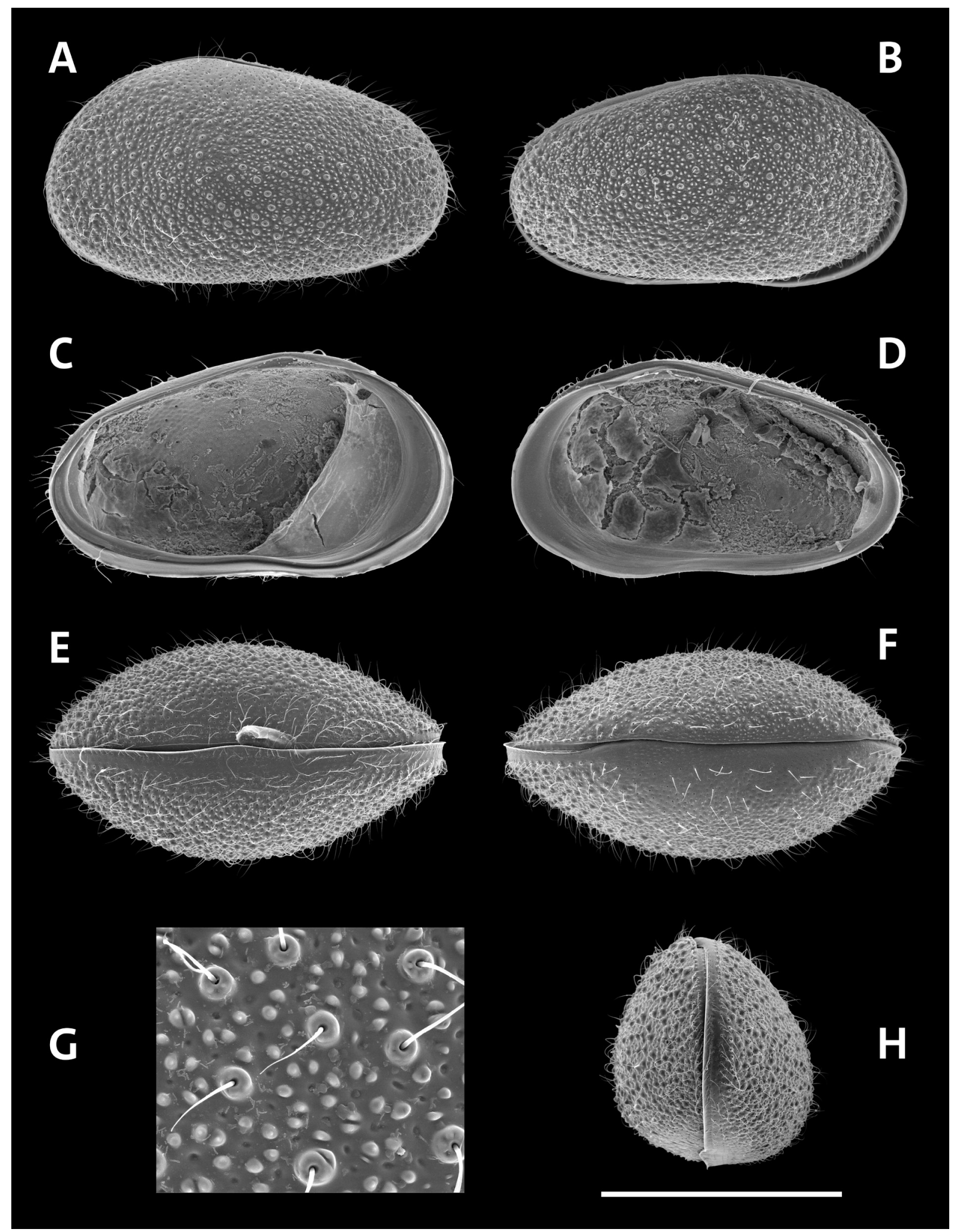

Fig. 1. Carapace and valves of Strandesia sanoamuangae. +. A: JH1138; B: JH1465; C-D: JH1134b; E: JH1137; F: JH1136; G: JH1135; H: JH1468. A. CpLL. B. CpRL. C. LVi. D. RVi. E. CpV. F. CpD. G. CpRI, detail. H. CpFr. Scale bar: A-F, $H=500 \mu \mathrm{m} ; \mathrm{G}=100 \mu \mathrm{m}$. 


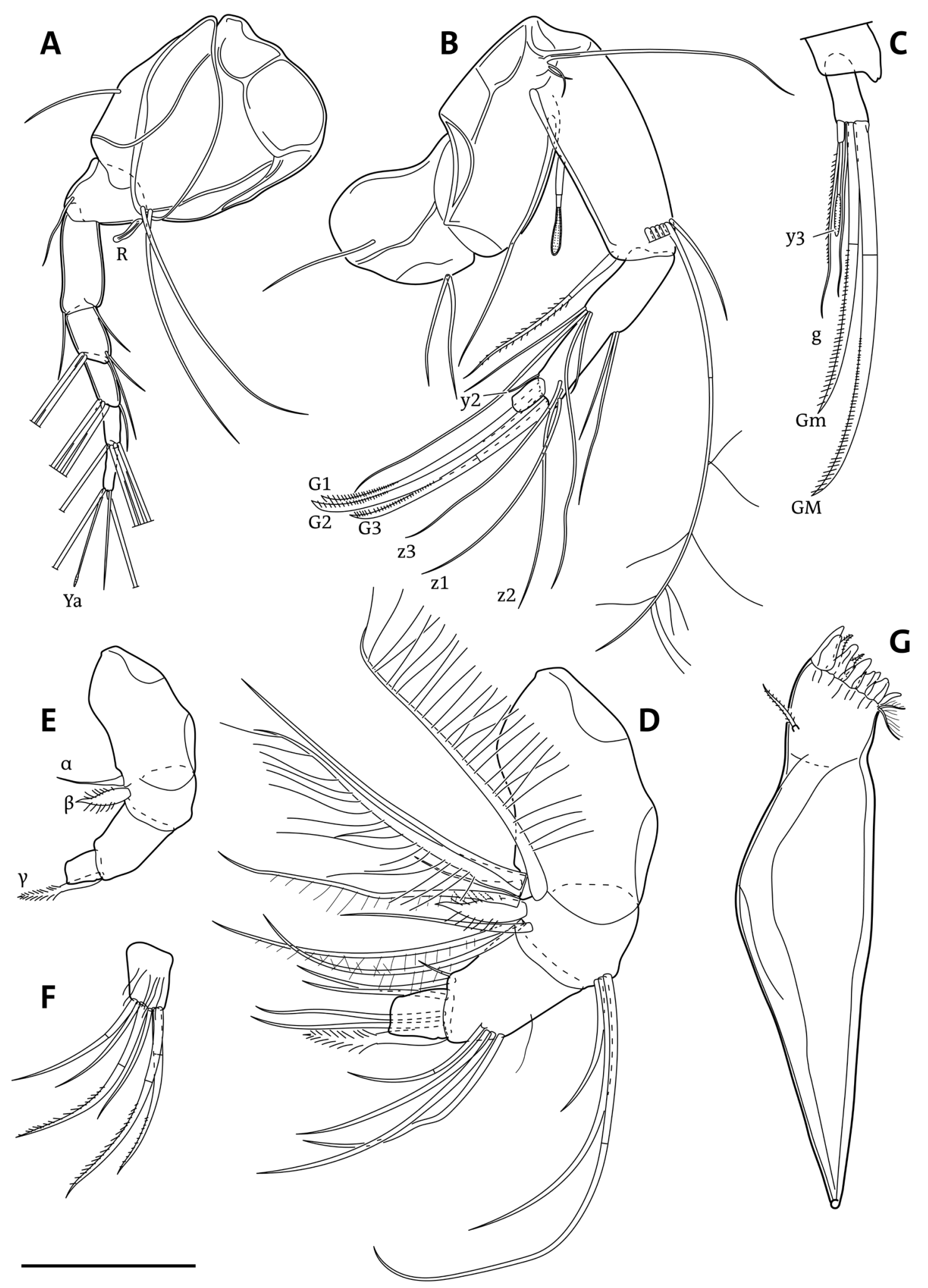

Fig. 2. Limbs of Strandesia sanoamuangae. ‥ A, F: AK007; B-C: AK003; D-E, G: AK006. A. A1 B. A2. C. A2, distal end of penultimate segment and terminal segment. D. Md-palp. E. Md-palp, showing $\alpha, \beta$ and $\gamma$ setae. F. Md-palp, terminal segment. G. Md-coxa. Scale bar: A-B, E, G $=100 \mu \mathrm{m} ; \mathrm{C}-\mathrm{D}$, $\mathrm{F}=60 \mu \mathrm{m}$. 
Md coxa (Fig. 2G) elongated and robust with an apical row of highly sclerotized teeth, largest at the dorsal edge with a general decrease in size toward the ventral edge. Teeth interspersed with setae with two notably strong setae covered with small setules ventral to the two largest teeth respectively and two short unequal hirsute setae ventral to the last tooth. Dorso-distal side of coxa with one short but stout seta.

Mx1 (Fig. 3A) (chaetotaxy incompletely illustrated) with a protopod, a two-segmented palp (endopod), three masticatory lobes (endites) and a large branchial plate (the latter not illustrated). Proximal segment of palp with six distal setae in close proximity (most ventral one longest but not reaching beyond the longest seta on second segment of palp) and one more proximal, short and slender seta. Second segment sub-quadrate, with three distal claws and three distal setae. Third endite with two large, weakly serrated distal bristles and a proximal seta reaching $1 / 3$ of the length of the bristles. First endite with two sidewaysdirected bristles (one approximately half the length of the other) and two slender proximal setae not reaching distal edge of endite.

T1 protopodite (Fig. 3B) with b- and d-setae subequal, b-seta about $4 / 5$ the length of d-setae. Protopodite with 14 mostly serrated setae; ten apical and four subapical. Palp (endopodite, not illustrated) elongated, with 3 unequal apical setae.

T2 (Fig. 3C) a walking leg with five segments. First segment with hirsute seta (d1). Second segment with hirsute seta (d2); d2 being ca $1 / 3$ the length of $d 1$. Third segment with one subapical hirsute seta (e). Fourth segment with two sub-segments ( $4 \mathrm{a}$ and $4 \mathrm{~b}$ respectively); segment $4 \mathrm{a}$ with one long apical hirsute seta (f) and segment $4 \mathrm{~b}$ with one seta ( $\mathrm{g}$ ), shorter than seta $\mathrm{f}$ and not reaching the end of the terminal segment. Fifth segment with one apical claw (h2) and one short ventral seta (h1) and one short dorsal seta (h3).

T3 (Fig 3D-E) a cleaning limb with three segments. First segment (the protopod) with three long setae (d1, d2 ventrally and dp dorsally); $\mathrm{d} 1$ and $\mathrm{d} 2$ with approximately equal length; dp longer than $\mathrm{d} 1 \mathrm{and} \mathrm{d} 2$ reaching distal edge of first endopodal segment. First endopodal segment with ventro-subapical seta e. Terminal endopodal segment with subapical seta $f$ and distal edge as pincer; seta $f$ not reaching distal edge of terminal segment. Distal edge of terminal segment with one comb-like seta (h2), one small recurved seta and one longer and distally hirsute seta (h3); seta h2 half the length of seta h3; seta h1 not observed.

CR (Fig. 3G) slender and straight with ventral side weakly serrated, a proximal weakly serrated claw, a distal weakly serrated claw, a proximal hirsute seta and a distal smooth seta. Proximal claw $3 / 4$ of the length of distal claw. Proximal seta about $1 / 3$ of the length of distal seta.

CR attachment (Fig. 3F) stout, with Triebel's loop in the middle of the distal part of main brand. Distal arc enclosing Triebel's loop obtusely connecting to short db; vb well-developed.

\section{Male \\ Unknown.}

\section{Measurements}

See Table 2.

\section{Material examined}

NEW CALEDONIA - Province Nord • 1 ; ; Koumac, Grottes de Koumac, up from Sentier de la Vierge; $20^{\circ} 30^{\prime} 55.8^{\prime \prime} \mathrm{S}, 164^{\circ} 19^{\prime} 55.9^{\prime \prime} \mathrm{W}$; 113 m a.s.1.; 5 Nov. 2016; J. Higuti \& K. Martens leg.; MNHN MNHN- 

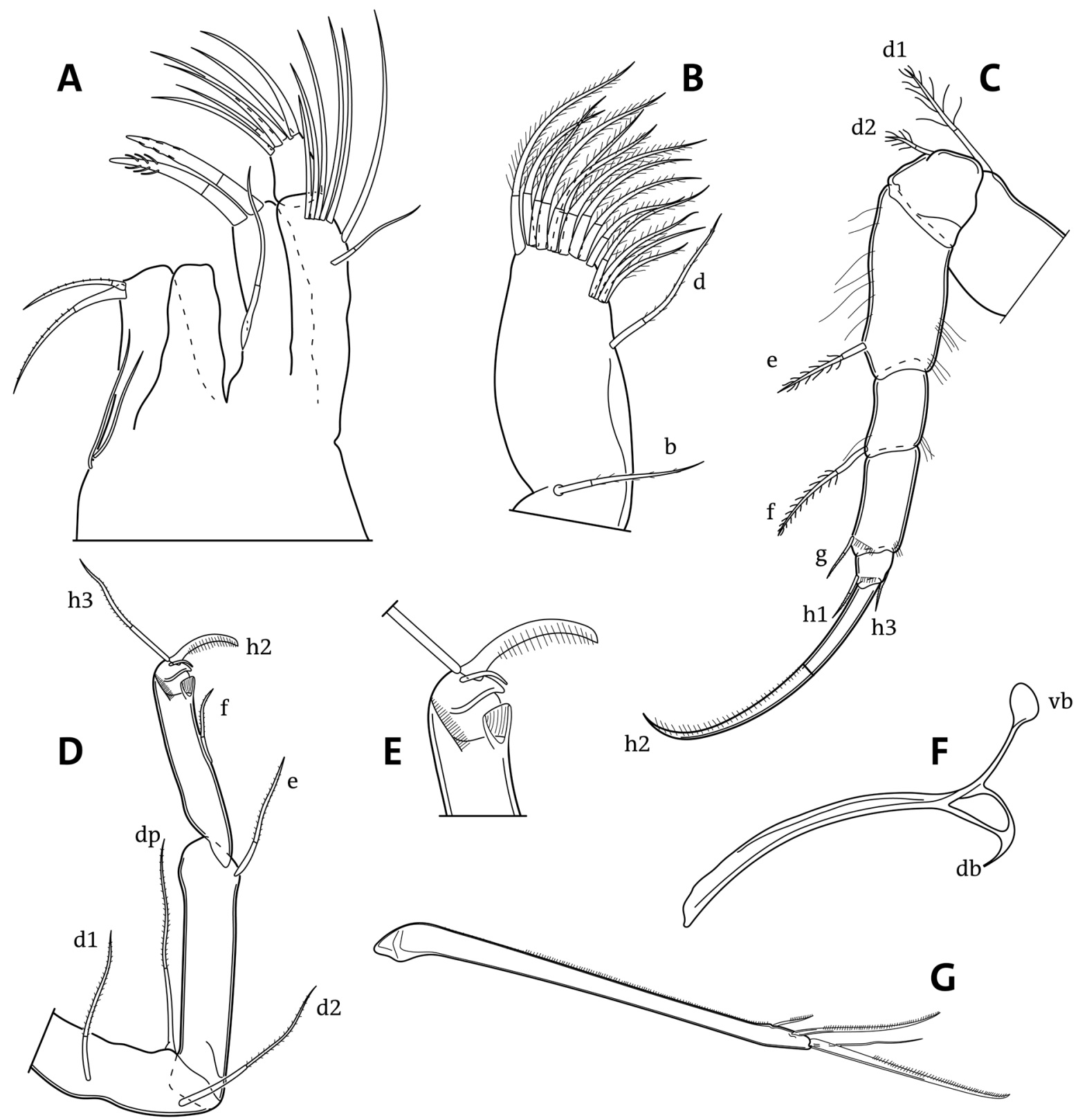

Fig. 3. Limbs of Strandesia sanoamuangae. ․ A: AK007; B-G: AK006. A. Mx1. B. T1, protopodite. C. T2. D. T3. E. T3, apical pincer. F. CR attachment. G. CR. Scale bar: A-B $=60 \mu \mathrm{m} ; \mathrm{C}-\mathrm{D}=100 \mu \mathrm{m}$; $\mathrm{E}=200 \mu \mathrm{m} ; \mathrm{F}-\mathrm{G}=150 \mu \mathrm{m}$. 
KISSEIH A. et al., A new species of Strandesia from New Caledonia

Table 2. Carapace and valve measurements of illustrated specimens of $S$. sanoamuangae and of type specimens of Strandesia mehesi sp. nov.

\begin{tabular}{|c|c|c|c|c|c|}
\hline \multirow{2}{*}{ Species } & \multirow{2}{*}{ Code } & \multirow{2}{*}{ Valve/Cp } & \multicolumn{3}{|c|}{ Measurements $(\mu \mathrm{m})$} \\
\hline & & & Length & Height & Width \\
\hline \multirow{7}{*}{$\begin{array}{l}\text { Strandesia } \\
\text { sanoamuangae }\end{array}$} & JH1134b & LVi & 841 & 469 & - \\
\hline & JH1134b & $\mathrm{RVi}$ & 820 & 462 & - \\
\hline & JH1136 & $\mathrm{CpD}$ & 834 & - & 446 \\
\hline & JH1137 & $\mathrm{CpV}$ & 831 & - & 461 \\
\hline & JH1138 & CpLI & 839 & 476 & - \\
\hline & JH1465 & CpRI & 834 & 446 & - \\
\hline & JH1468 & $\mathrm{CpFr}$ & - & 485 & 424 \\
\hline \multirow{11}{*}{$\begin{array}{l}\text { Strandesia } \\
\text { mehesi sp. nov. }\end{array}$} & MNHN-IU-2014-20305 (AK008b) & $\mathrm{RVi}$ & 768 & 461 & - \\
\hline & MNHN-IU-2014-20305 (AK008b) & LVi & 804 & 464 & - \\
\hline & MNHN-IU-2014-20308 (KM3706) & CpRL & 793 & 435 & - \\
\hline & MNHN-IU-2014-20309 (KM3707) & $\mathrm{CpRL}$ & 811 & 433 & - \\
\hline & MNHN-IU-2014-20310 (KM3708) & CpRL & 803 & 437 & - \\
\hline & MNHN-IU-2014-20311 (KM3709) & CpRL & 833 & 447 & - \\
\hline & MNHN-IU-2014-20312 (KM3710) & CpRL & 781 & 448 & - \\
\hline & MNHN-IU-2014-20308 (KM3706) & $\mathrm{CpV}$ & 798 & - & 446 \\
\hline & MNHN-IU-2014-20309 (KM3707) & $\mathrm{CpD}$ & 811 & - & 438 \\
\hline & MNHN-IU-2014-20310 (KM3708) & CpLL & 807 & 467 & - \\
\hline & MNHN-IU-2014-20312 (KM3710) & $\mathrm{CpFr}$ & - & 484 & 451 \\
\hline
\end{tabular}

HYNC-HYNC-1104 • 1 क; Koumac, Grottes de Koumac, up from Sentier de la Vierge; 20 $32^{\prime} 2.5^{\prime \prime}$ S, 164¹9'40.1" W; 32 m a.s.1.; 6 Nov. 2016; J. Higuti \& K. Martens leg.; MNHN MNHN-HYNC-1107

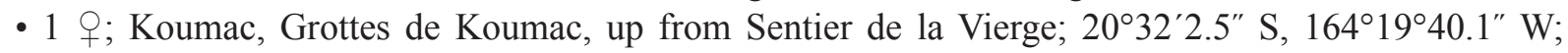
$32 \mathrm{~m}$ a.s.1.; 6 Nov. 2016; J. Higuti \& K. Martens leg.; MNHN MNHN-HYNC-1108 • 1 \&; Koumac, Koumac River; $20^{\circ} 32^{\circ} 23^{\prime \prime}$ S, $164^{\circ} 16^{\prime} 4.2^{\prime \prime}$ W; 2 m a.s.1.; 7 Nov. 2016; J. Higuti \& K. Martens leg.;

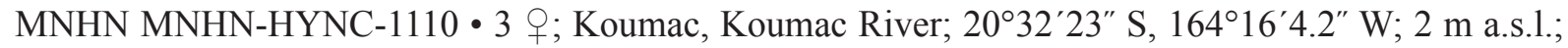
7 Nov. 2016; J. Higuti \& K. Martens leg.; MNHN MNHN-HYNC-1111 • 1 q; Koumac, Néhoué

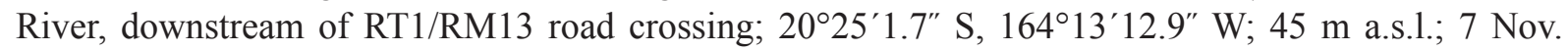
2016; J. Higuti \& K. Martens leg.; MNHN MNHN-HYNC-1121 • 1 q; Kaala Gomen, River Iouanga. near Tegon ; 2041'1.9" S, 164²3'40.7" W; 4 m a.s.1.; 9 Nov. 2016; J. Higuti \& K. Martens leg.; MNHN MNHN-HYNC-1127 • 1 क; Kaala Gomen, River Iouanga, near Gamai; 2041'13.9" S, 164²9'9.7" W; 16 m a.s.1.; 9 Nov. 2016; J. Higuti \& K. Martens leg.; MNHN MNHN-HYNC-1129

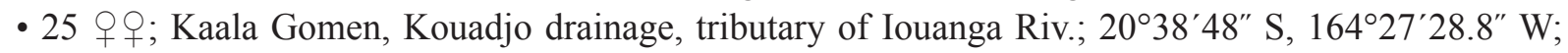
84 m a.s.l.; 9 Nov. 2016; J. Higuti \& K. Martens leg.; MNHN MNHN-HYNC-1131 • 20 o ; ; Kaala Gomen, River Ouémou, between Ouemou and Oueholle; 20³6'15.3" S, 164³3'16.7” W; 129 m a.s.1.; 9 Nov. 2016; J. Higuti \& K. Martens leg.; MNHN MNHN-HYNC-1135• 1 q; Hienghene, Hienghene 
River; $20^{\circ} 44^{\prime} 2.8^{\prime \prime} \mathrm{S}, 1^{\circ} 4^{\circ} 54^{\prime} 3.1^{\prime \prime} \mathrm{W} ; 10$ m a.s.1.; 13 Nov. 2016; J. Higuti \& K. Martens leg.; MNHN

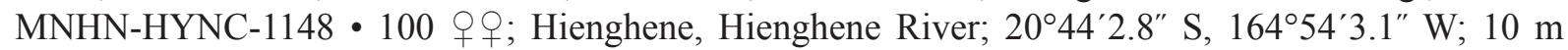
a.s.l.; 13 Nov. 2016; J. Higuti \& K. Martens leg.; MNHN MNHN-HYNC-1150 • 1 ; Hienghene, Hienghene River; $20^{\circ} 44^{\prime} 22.4^{\prime \prime} \mathrm{S}, 1^{\circ} 4^{\circ} 52^{\prime} 35.9^{\prime \prime} \mathrm{W} ; 11 \mathrm{~m}$ a.s.1.; 14 Nov. 2016; J. Higuti \& K. Martens leg.; MNHN MNHN-HYNC-1154 • 1 क ; Hienghene, Hienghene River; 2044'22.4" S, 16452'35.9” W; 11 m a.s.1.; 14 Nov. 2016; J. Higuti \& K. Martens leg.; MNHN MNHN-HYNC-1155 • 5 q ; Hienghene,

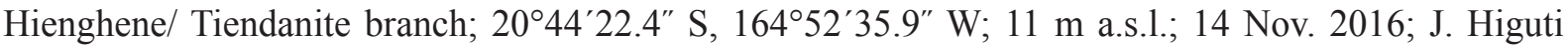
\& K. Martens leg.; MNHN MNHN-HYNC-1156 • 1 q; Hienghene, Hienghene/ Tiendanite branch; $20^{\circ} 44^{\prime} 23.1^{\prime \prime} \mathrm{S}, 164^{\circ} 52^{\prime} 35.4^{\prime \prime} \mathrm{W} ; 11 \mathrm{~m}$ a.s.1.; 14 Nov. 2016; J. Higuti \& K. Martens leg.; MNHN MNHNHYNC-1157 • 5 우; Hienghene, Hienghene/ Tiendanite branch; 2044'23.1" S, 16452'35.4" W; $11 \mathrm{~m}$ a.s.1.; 14 Nov. 2016; J. Higuti \& K. Martens leg.; MNHN MNHN-HYNC-1158 5 q ㅇ ; Hienghene, Oué Hava, Tipindje River drainage; $20^{\circ} 45^{\prime} 37.5^{\prime \prime} \mathrm{S}, 1^{\circ} 5^{\circ} 1^{\prime} 39.3^{\prime \prime} \mathrm{W} ; 19 \mathrm{~m}$ a.s.1.; 15 Nov. 2016; J. Higuti \& K. Martens leg.; MNHN MNHN-HYNC-1164・1 + ; Hienghene, Oué Hava, Tipindje River drainage; $20^{\circ} 45^{\prime} 37.5^{\prime \prime} \mathrm{S}, 165^{\circ} 1^{\prime} 39.3^{\prime \prime} \mathrm{W} ; 19$ m a.s.l.; 15 Nov. 2016; J. Higuti \& K. Martens leg.; MNHN MNHNHYNC-1165 • 1 9; Hienghene, Pwé Hiit (Pwé Ciit); 2046'59.1" S, $165^{\circ} 5^{\prime} 49.7$ " W; 30 m a.s.1.; 16 Nov. 2016; leg. J. Higuti \& K. Martens; MNHN MNHN-HYNC-1172 • 15 q + ; Houailou, Rivière La Túú Tuu River; $21^{\circ} 15^{\prime} 53^{\prime \prime}$ S, 165³5'49.8" W; 7 m a.s.1.; 14 Nov. 2017; leg. J Higuti \& K. Martens; MNHN MNHN-HYNC-1272 • 1 क ; Kouaoua, Fa Uru, right bank tributary of the Kouaoua River; $21^{\circ} 29^{\prime} 2.1^{\prime \prime}$ S, 165'46'41.6" W; 26 m a.s.l.; 21 Nov. 2017; J. Higuti \& K. Martens leg.; MNHN MNHN-HYNC-2522 - 20 우; Ponérihouen, Goyeta; $21^{\circ} 5^{\prime} 55.2^{\prime \prime} \mathrm{S}, 165^{\circ} 21^{\prime} 20.4^{\prime \prime} \mathrm{W} ; 13 \mathrm{~m}$ a.s.1.; 29 May 2018; J. Higuti \& K. Martens leg.; MNHN MNHN-HYNC-2587 • 2 우; Touho, Ouanache; $20^{\circ} 44^{\prime} 51^{\prime \prime}$ S, $165^{\circ} 3^{\prime} 41.1^{\prime \prime} \mathrm{W}$; $11 \mathrm{~m}$ a.s.l.; 31 May 2018; J. Higuti \& K. Martens leg.; MNHN MNHN-HYNC-3005 • 4 + $q$; Voh, Temala River drainage; $20^{\circ} 51^{\prime} 10.9^{\prime \prime} \mathrm{S}, 164^{\circ} 42^{\prime} 5.6^{\prime \prime} \mathrm{W} ; 23 \mathrm{~m}$ a.s.1.; 2 Jun. 2018; J. Higuti \& K. Martens leg.; MNHN MNHN-HYNC-3013 • 3 q o ; Voh, Temala River drainage; $20^{\circ} 51^{\prime} 9.9^{\prime \prime} \mathrm{S}, 164^{\circ} 42^{\prime} 1.7^{\prime \prime} \mathrm{W}$; 16 m a.s.1.; 2 Jun. 2018; J. Higuti \& K. Martens leg.; MNHN MNHN-HYNC-3014 • 2 q $q$; Voh, Congo River drainage; $20^{\circ} 55^{\prime} 15.7^{\prime \prime} \mathrm{S}, 1^{\circ} 4^{\circ} 44^{\prime} 56^{\prime \prime} \mathrm{W} ; 20$ m a.s.1.; 2 Jun. 2018; J. Higuti \& K. Martens leg.; MNHN MNHN-HYNC-3018 - Province Sud • 30 q ; ; Bourail, Rivière du Cap - Embouchure; $21^{\circ} 30^{\prime} 45.6^{\prime \prime} \mathrm{S}, 165^{\circ} 17^{\prime} 42^{\prime \prime} \mathrm{W} ; 8 \mathrm{~m}$ a.s.l.; 11 Nov. 2017; J. Higuti \& K. Martens leg.; MNHN MNHN-

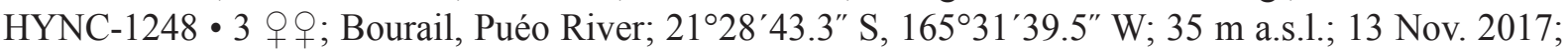
J. Higuti \& K. Martens leg.; MNHN MNHN-HYNC-1264 • 20 q 9 ; Bourail, Puéo drainage - Tribu Bouirou; 2126'19.1" S, 165³1'55.4" W; 171 m a.s.1.; 13 Nov. 2017; J. Higuti \& K. Martens leg.; MNHN MNHN-HYNC-1265 • 50 우; Bourail, Boghen drainage; $21^{\circ} 35^{\prime} 43.1^{\prime \prime} \mathrm{S}, 165^{\circ} 33^{\prime} 10.3^{\prime \prime} \mathrm{W} ; 8 \mathrm{~m}$ a.s.1.; 13 Nov. 2017; J. Higuti \& K. Martens leg.; MNHN MNHN-HYNC-1268 • 1 \%; Bourail, Boghen drainage; $21^{\circ} 35^{\prime} 43.1^{\prime \prime} \mathrm{S}, 165^{\circ} 33^{\prime} 10.3^{\prime \prime}$ W; 8 m a.s.1.; 13 Nov. 2017; J. Higuti \& K. Martens leg.; MNHN MNHN-HYNC-1269 • 5 우; Bourail, Nera River; $21^{\circ} 34^{\prime} 56.8^{\prime \prime} \mathrm{S}, 165^{\circ} 29^{\prime} 43.6^{\prime \prime} \mathrm{W} ; 6$ m a.s.1.; 15 Nov. 2017; J. Higuti \& K. Martens leg.; MNHN MNHN-HYNC-1274 10 우; La Foa, tributary of La Foa Riv.; $21^{\circ} 42^{\prime} 31.8^{\prime \prime} \mathrm{S}, 165^{\circ} 48^{\prime} 26.2^{\prime \prime} \mathrm{W} ; 7$ m a.s.1.; 16 Nov. 2017; J. Higuti \& K. Martens leg.; MNHN MNHN-HYNC-1285 • 5 우; Boulouparis, Oua Tchoué drainage; $21^{\circ} 47^{\prime} 33.7^{\prime \prime} \mathrm{S}, 166^{\circ} 0^{\prime} 55.5^{\prime \prime} \mathrm{W} ; 235 \mathrm{~m}$ a.s.1.; 18 Nov. 2017; J. Higuti \& K. Martens leg.; MNHN MNHN-HYNC-2502 • 5 우; Boulouparis, reservoir; 21 ${ }^{\circ} 50^{\prime} 54^{\prime \prime} \mathrm{S}, 165^{\circ} 55^{\prime} 35.5^{\prime \prime} \mathrm{W} ; 58 \mathrm{~m}$ a.s.1.; 18 Nov. 2017; J. Higuti \& K. Martens leg.; MNHN

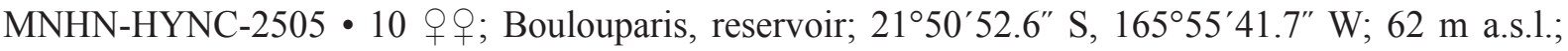
18 Nov. 2017; J. Higuti \& K. Martens leg.; MNHN MNHN-HYNC-2508 • 5 q ; ; Thio, Xwê Xârâge (Karingué) at Merigu; $21^{\circ} 41^{\prime} 8.2^{\prime \prime} \mathrm{S}, 166^{\circ} 5^{\prime} 20.7^{\prime \prime} \mathrm{W} ; 58 \mathrm{~m}$ a.s.1.; 23 May 2018; J. Higuti \& K. Martens

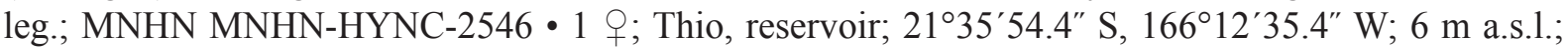
25 May 2018; J. Higuti \& K. Martens leg.; MNHN MNHN-HYNC-2562 200 q $q$; Thio, reservoir on side of RP10; $21^{\circ} 35^{\prime} 50.4^{\prime \prime}$ S, 166 12'35" W; 11 m a.s.1.; 25 May 2018; J. Higuti \& K. Martens leg.; MNHN MNHN-HYNC-2564 • 2 우; Paita, Small lake at Mango Pépinière; $21^{\circ} 59^{\prime} 2.5^{\prime \prime}$ S, $166^{\circ} 12^{\prime} 56.7^{\prime \prime} \mathrm{W}$; 11 m a.s.l.; 7 Jun. 2018; J. Higuti \& K. Martens leg.; MNHN MNHN-HYNC-3063 • 50 क o ; Paita, Small lake at Mango Pépinière; 21 ${ }^{\circ} 59^{\prime} 2.6^{\prime \prime} \mathrm{S}, 1^{\circ} 66^{\circ} 12^{\prime} 55^{\prime \prime} \mathrm{W} ; 20$ m a.s.1.; 7 Jun. 2018; J. Higuti \& K. Martens leg.; MNHN MNHN-HYNC-3064. 


\section{Remarks}

The present populations from New Caledonia have been identified as Strandesia sanoamuangae (Savatenalinton \& Martens, 2010) from Thailand, because of the strong resemblance in shape and ornamentation of the carapace. There are some small morphological differences in the New Caledonian populations: the carapace is slightly less arched in the dorsal and ventral views at its greatest width; its sinuous protrusion in the ventral view is slightly anterior to the greatest carapace width; the LV overlap of the RV is slightly narrower, and the periphery of the LV is inconspicuous at the dorsal margin in the right lateral view. Also, the LV of the Thai specimens of S. sanoamuangae seems to lack the pronounced inner list that is visible in the specimens from New Caledonia, but this could be a matter of degree of calcification, and we assume this list is also present in the Thai specimens.

Strandesia sanoamuangae also somewhat resembles Strandesia perakensis (Victor \& Fernando, 1981), but the carapace of this latter species lacks tubercles and is set with long sensilla and spines. The small pits on its $\mathrm{Cp}$ are also markedly visible from the inner view of the valves (see illustrations in Victor \& Fernando 1981 and the re-description in Savatenalinton \& Martens 2010).

Even though the present species seems easily identifiable, we decided to document its range extension with a full re-description as convergent evolution in non-marine ostracods in general, and in the Cypricercinae in particular, is very high. See for example the cases of Rudjakoviella prolongata (Triebel, 1962) from a Venezuelan Island and Strandesia bicornuta Hartmann, 1964 from southern India and of Bradleytriebella lineata (Victor \& Fernando,1981) and Neostrandesia striata Ferreira et al., 2019 (Ferreira et al. 2019).

\section{Strandesia mehesi sp. nov. urn:Isid:zoobank.org:act:4A4696B2-7442-4F3F-A3A4-CBA9CF203806}

Figs 4-7

\section{Differential diagnosis}

The present species belongs to the $S$. vinciguerrae/S. vavrai - group within the genus, which is characterized by a carapace with rounded appearance in lateral view, with the greatest height situated well in front of the middle, a LV overlapping the RV on all sides, and a slight to pronounced skewed asymmetry of the valves in frontal view.

The new species differs from both $S$. vinciguerrae and $S$. vavrai in both size and shape of the valves. Strandesia vinciguerrae appears to be its closest relative, but both valves (especially the LV) in the new species are more elongated, the dorsal margins are more equally sloping towards the posterior side and an anterior selvage on the RV appears to be missing in this species. See below for further discussion on the identity of Strandesia vinciguerrae. The valves of Strandesia vavrai (Müller 1898: plate 16, figs 1-6) are even shorter and the dorsal margins of both valves are almost fully symmetrically rounded. Strandesia kraepelini (G.W. Muller, 1906), described as Cypris kraepelini from Java (Müller, 1906), also belongs in this group. This species resembles Strandesia mehesi sp. nov. from New Caledonia, but it is more elongated, with a long straight part of the dorsal margin (rounded in the new species) and also does not show a trace of the anterior selvage in the RV which is present in the specimens from New Caledonia (see redescription in Savatenalinton \& Martens, 2010). Several other species resemble S. mehesi sp. nov., but these require further discussion (see below).

\section{Etymology}

The present species is named after Gyula Méhes (Budapest, Hungary), a student of E. Daday, who wrote the first comprehensive account of the freshwater ostracods of the New Caledonian archipelago. 

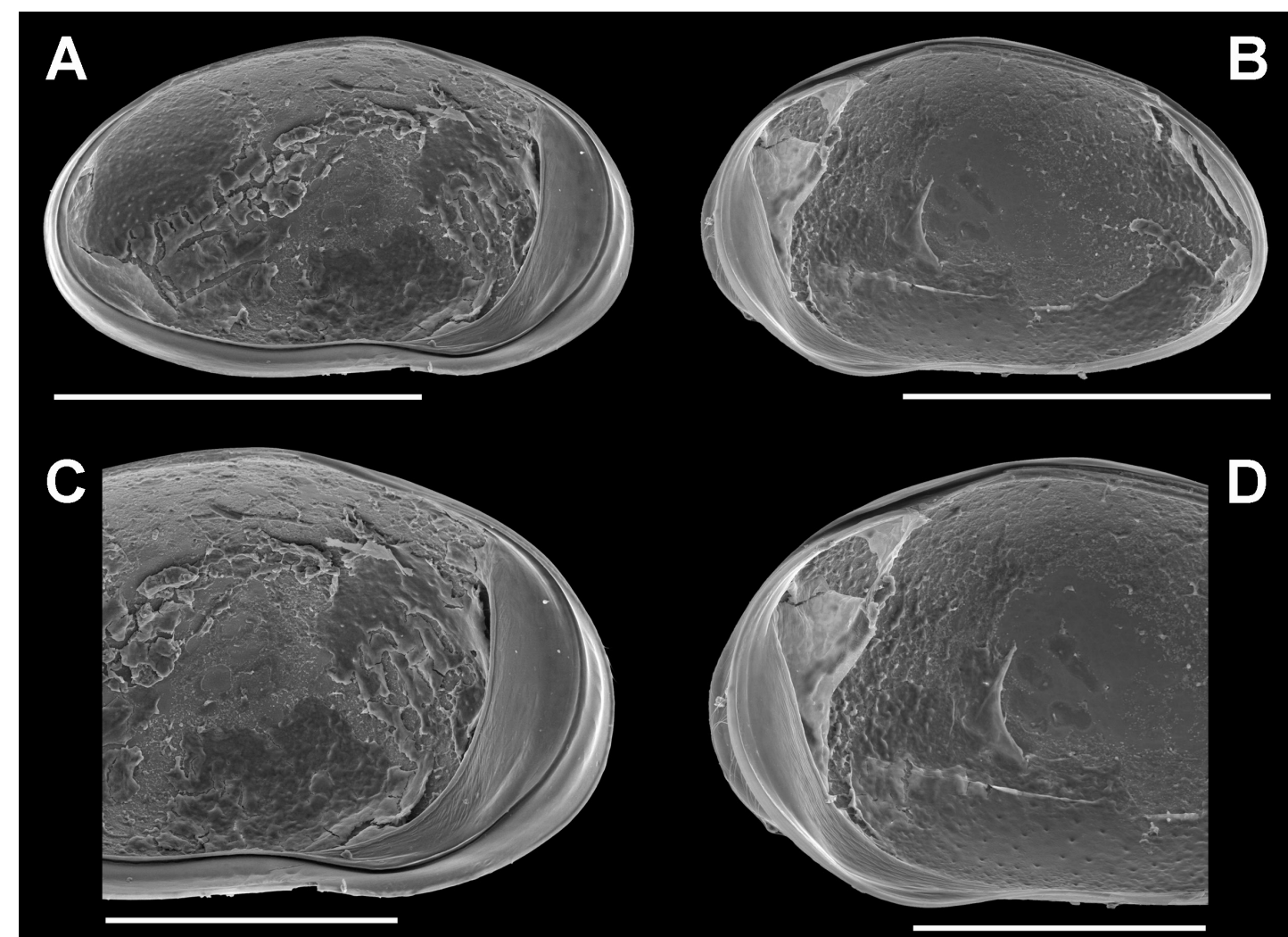

D
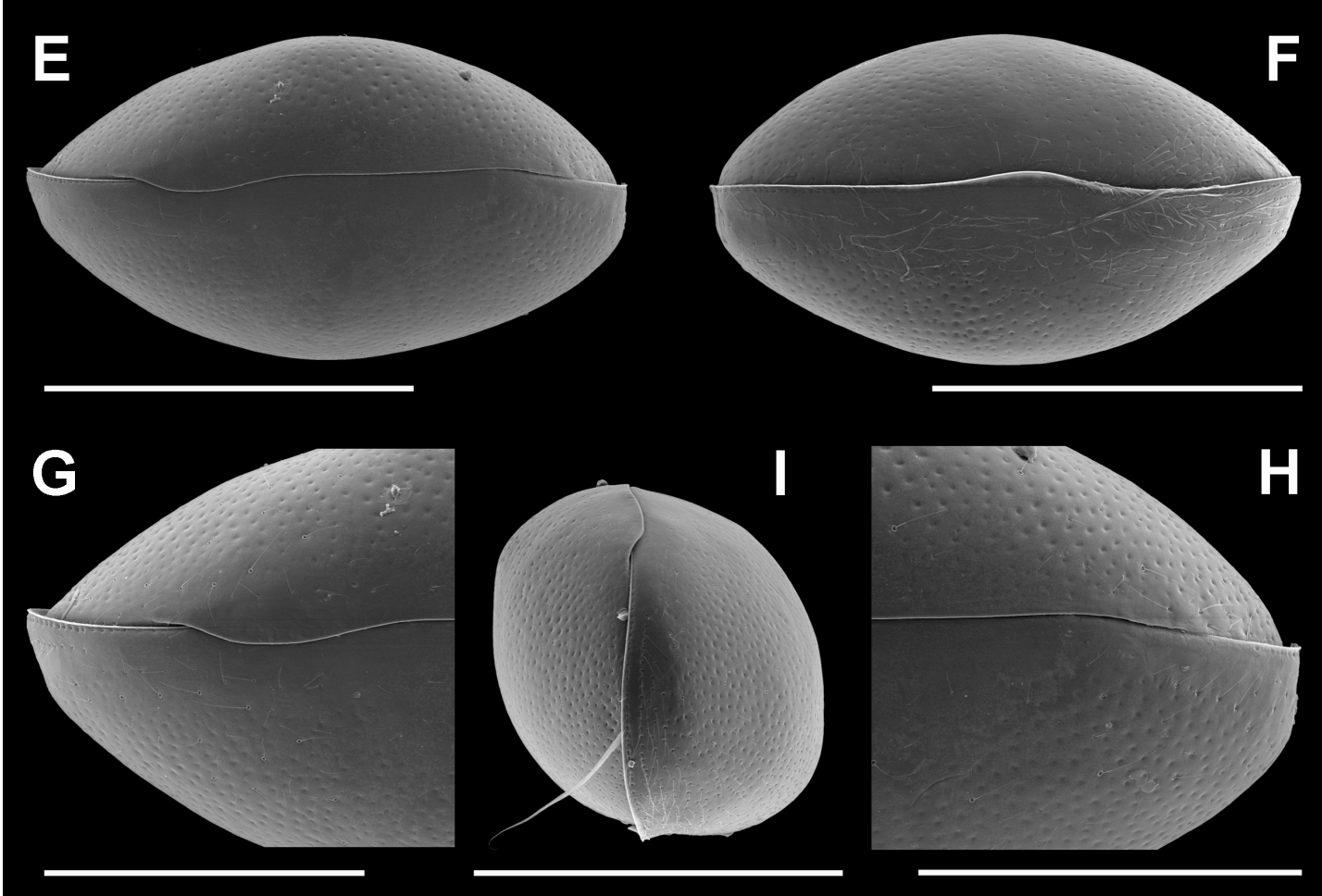

Fig. 4. Carapace and valves of Strandesia mehesi sp. nov. $q$, paratypes; A-D: MNHN-HYNCIU-2014-20305; E, G-H: MNHN-IU-2014-20309; F: MNHN-IU-2014-20308; I: MNHN-IU-201420312. A. LVi. B. RVi. C. LVi, anterior part detail. D. RVi, anterior part detail. E. CpD. F. CpV. G. CpD, anterior part detail. H. CpD, posterior part detail. I. CpFr. Scale bars: A-B, E-F, I = $500 \mu \mathrm{m}$; C-D, G-H $=300 \mu \mathrm{m}$. 


\section{Material examined}

\section{Holotype}

NEW CALEDONIA - P; Province Nord, Houailou, Rivière La Túú - Tuu River; $21^{\circ} 15^{\prime} 53^{\prime \prime}$ S, $165^{\circ} 35^{\prime} 49.8^{\prime \prime}$ W; 7 m a.s.1.; 14 Nov. 2017; J. Higuti \& K. Martens leg.; soft parts dissected in glycerine in a sealed slide, valves stored dry in a micro-palaeontological slide; sample HYNC.1272; MNHN MNHNHYNC-IU-2014-20304. Accompanying ostracod fauna: Strandesia sanoamuangae Savatenalinton \& Martens, 2010. Water temperature at time of collecting: $27.1^{\circ} \mathrm{C}$; electrical conductivity: $95.6 \mu \mathrm{S} / \mathrm{cm}$; $\mathrm{pH}: 7.5$.

\section{Paratypes}

NEW CALEDONIA - Province Nord $• 3+q$; same collection data as for holotype; soft parts dissected in glycerine in a sealed slide, valves stored dry in a micro-palaeontological slide; MNHN MNHNIU-2014-20305 to MNHN-IU-2014-20307. - 5 o $O$; same collection data as for holotype; undissected and stored dry in micropalaeontological slides after use for SEM; MNHN MNHN-IU-2014-20308 to MNHN-IU-2014-20312. • 10 우; same collection data as for holotype; stored in EtOH; MNHN MNHN-IU-2014-20313.

\section{Description}

\section{Female}

CpLL (Fig. 5A) sub-ovate and dorsally arched with greatest height situated slightly in front of the middle; anterior and posterior margins rounded, posterior margin slightly narrower; RV slightly overlapping LV dorsally. CpRL (Fig. 5B-F) sub-ovate and dorsally arched with greatest height situated slightly anterior of mid length; dorsal arc shallower than in CpLL; LV overlapping RV anteriorly, ventrally and posteriorly; overlap greatest anteriorly and posteriorly. $\mathrm{CpD}$ (Fig. 4E, G-H) and $\mathrm{CpV}$ (Fig. 4F) subelliptical, with greatest height at ca mid-length, lateral margins sloping to blunt anterior and posterior extremities; LV margin in ventral view sinuous with protrusion at greatest carapace width. CpFr (Fig. 4I) slightly skewed, with RV higher than LV. Cp surface in lateral views (Fig. 5G-H) with scattered rimmed pores with sensilla and small pits fading toward the centre of the valves; pores, with sensilla not rimmed, denser antero-ventrally.

LVi (Fig. 4A, C) with calcified inner lamella wider anteriorly, an internal groove along valve margin. RVi (Fig. 4B, D) with calcified inner lamella wider anteriorly, and with anterior selvage marginally inwardly displaced.

A1 (Fig. 6A) with seven segments. All segments with apical setae. First segment with 1 short dorsal seta and two long ventro-apical setae. Wouter's Organ not observed. Second segment trapezoid-like with one short apical seta at dorsal side and one large, ventral Rome Organ (R). Third segment longest of all segments with two short setae; one dorsal and one ventral. Fourth segment with two long dorsal setae and two short dorsal setae; one of short setae approximately half as long as other. Fifth segment with three long dorsal and one short ventral setae. Sixth segment with four long apical setae. Seventh segment with one short aesthetasc seta (Ya), one long seta twice as long as Ya and two long setae.

A2 (Fig. 6B-C) biramous with two-segmented protopod, a reduced exopod and three endopodal segments. First protopodal segment with two unequal ventral setae. Second protopodal segment with one long seta. Exopod a small plate with one long seta and two very short but unequal setae. First endopodal segment with one thin ventral aesthetasc, one long apical seta not reaching beyond the last endopodal segment and six natatory setae (five long and one short); the long natatory setae not extending beyond tips of apical claws. Second endopodal segment with two unequal dorsal setae; a group of four ventral setae ("t"-setae; two long and two short); one short seta approximately equalling the length of the terminal segment; three serrated apical claws (G1, G2 and G3) and three apical setae (z1, z2 and z3). 


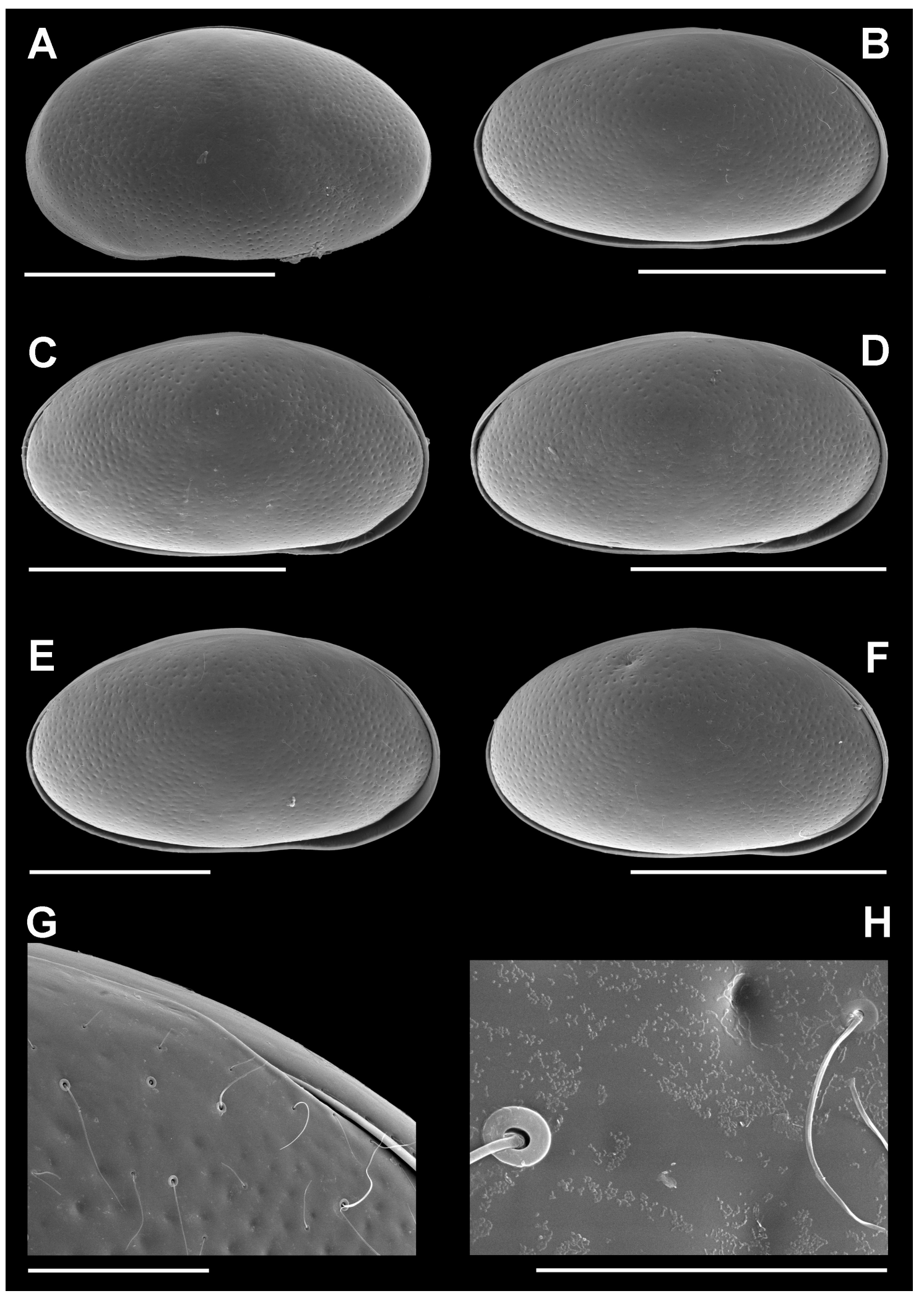

Fig. 5. Carapace and valves of Strandesia mehesi sp. nov. + , paratypes; A,E: MNHN-IU-2014-20310; B,G: MNHN-IU-2014-20311; C: MNHN-IU-2014-20308; D: MNHN-IU-2014-20309; F, H: MNHNIU-2014-20312. A. CpLL. B. CpRL. C. CpRL. D. CpRL. E. CpRL. F. CpRL. G. CpRL, surface detail. H. CpRL, surface detail. Scale bars: $A-F=500 \mu \mathrm{m} ; \mathrm{G}=300 \mu \mathrm{m} ; \mathrm{H}=30 \mu \mathrm{m}$. 


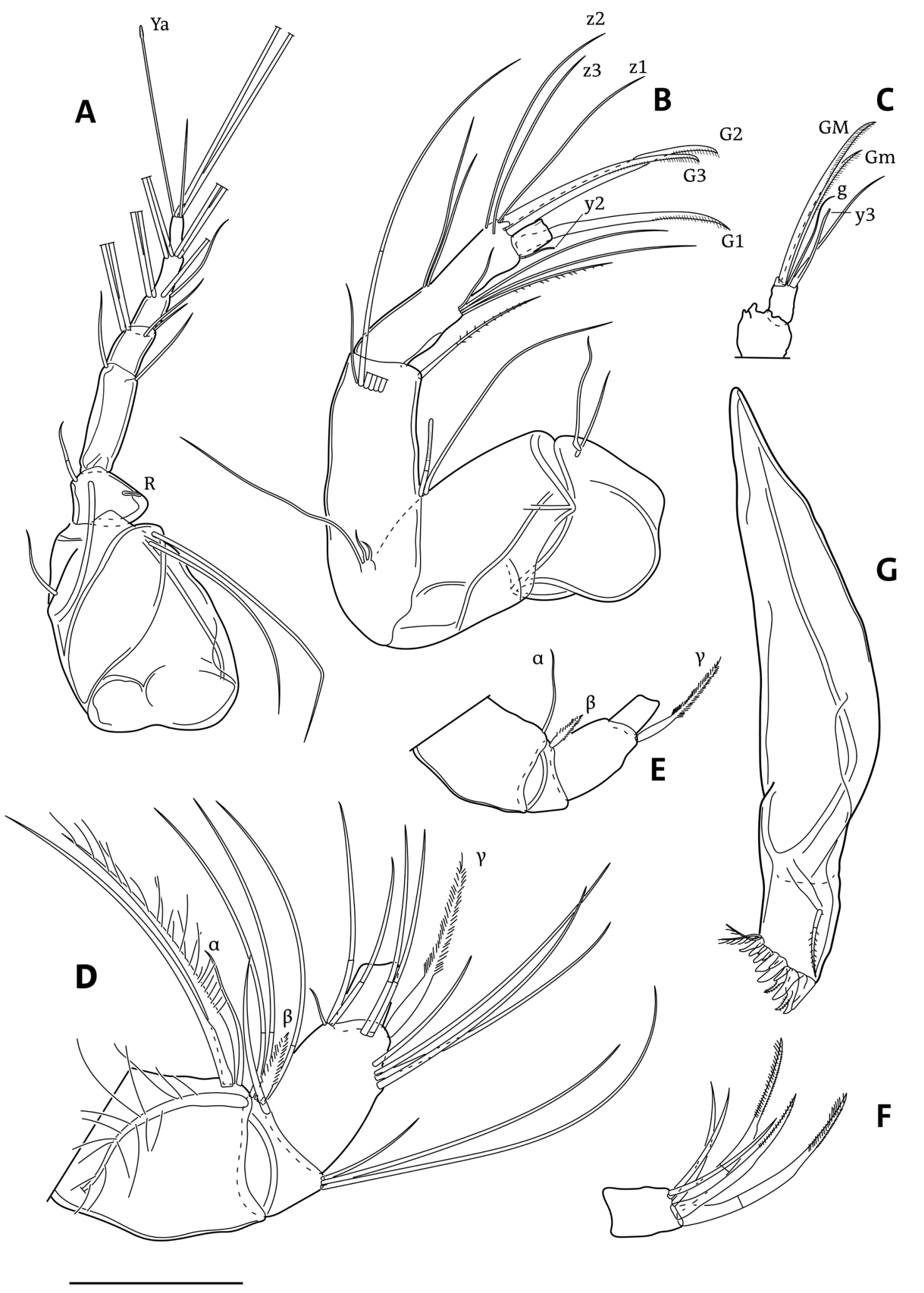

Fig. 6. Limbs of Strandesia mehesi sp. nov. ․ A,D-E, G: holotype MNHN-HYNC-IU-2014-20304; B-C, F: paratype MNHN-IU-2014-20307. A. A1. B. A2. C. A2, distal end of penultimate segment and terminal segment. D. Md-palp. E. Md-palp, showing $\alpha, \beta$ and $\gamma$ setae. F. Md-palp, terminal segment. G. Md-coxa. Scale bars: A-C, E, G $=100 \mu \mathrm{m} ; \mathrm{D}, \mathrm{F}=60 \mu \mathrm{m}$. 


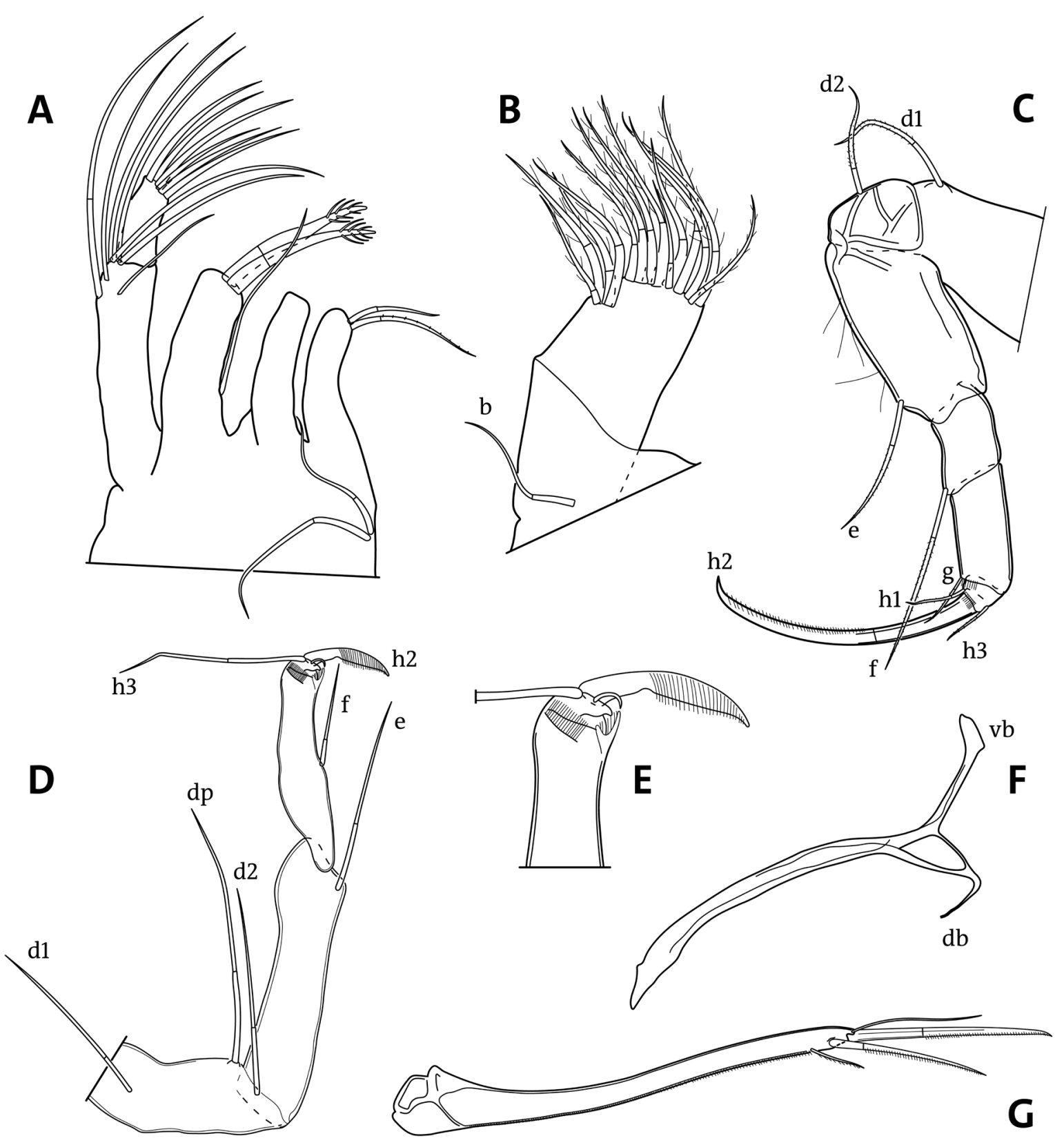

Fig. 7. Limbs of Strandesia mehesi sp. nov. O. A-E: holotype MNHN-HYNC-IU-2014-20304; F: paratype MNHN-IU-2014-20307; G: paratype MNHN-IU-2014-20306. A. Mx1. B. T1, protopodite. C. T2. D. T3. E. T3, apical pincer. F. CR attachment. G. CR. Scale bar: A-B $=60 \mu \mathrm{m} ; \mathrm{C}-\mathrm{D}=100 \mu \mathrm{m}$; $\mathrm{E}=200 \mu \mathrm{m} ; \mathrm{F}-\mathrm{G}=150 \mu \mathrm{m}$. 
Terminal segment with two serrated claws, one long (GM) and one short (Gm); one aesthetasc fused over a short distance with an accompanying seta and one g-seta.

Md Palp (Fig. 6D-F) with four segments. First segment with four ventral setae; two long plumose setae, one long smooth seta and one short $\alpha$-seta; this segment also with a small respiratory plate (not shown). Second segment with four ventral setae (one slender hirsute $\beta$-seta about $1 / 2$ the length of $\alpha$-seta, three long hirsute setae and one short smooth seta) and three dorsal subapical setae (one long, one about $3 / 4$ the length of first and the shortest about $1 / 4$ of first). Third segment with six apical setae (one long $\gamma$-seta hirsute at the distal half of its length, four smooth setae and one short setae about $2 / 3$ the length of the terminal segment) and four unequal dorsal subapical setae. Fourth segment (Fig. 6F) with three claws and three setae apically, claws longer than setae.

Md coxa (Fig. 6G) elongated and robust with an apical row of highly sclerotized teeth, largest at the dorsal edge with a general decrease in size toward the ventral edge. Teeth interspersed with setae with two notably strong setae covered with small setules ventral to the two largest teeth respectively and two short unequal hirsute setae ventral to the last tooth. Dorso-distal side of coxa with one short but stout seta.

Mx1 (Fig. 7A) (chaetotaxy incompletely illustrated) with a protopod, a two-segmented palp (endopod), three masticatory lobes (endites) and a large branchial plate (the latter not illustrated). Proximal segment of palp with six antero-distal setae (most ventral one longest reaching beyond the longest seta on second segment of palp) and one medial slender seta. Second segment elongated (length twice as width) with three distal claws and three distal setae. Third endite with two large and strongly serrated distal bristles and a proximal seta reaching higher than half the length of the bristles. First endite with two sidewaysdirected bristles (one approximately half the length of the other) and two slender proximal setae not reaching distal edge of the endite.

T1 protopodite (Fig. 7B) with b seta, d seta not observed. Protopodite with 14 mostly serrated setae; ten apical and four subapical. Palp (endopodite - not illustrated) elongated, with three unequal apical setae.

T2 (Fig. 7C) a walking leg with five segments. First segment with hirsute seta (d1). Second segment with hirsute seta (d2); $d 2$ being ca $3 / 4$ the length of $d 1$. Third segment with one subapical hirsute seta e. Fourth segment with two sub-segments (4a and $4 \mathrm{~b}$ respectively); segment $4 \mathrm{a}$ with one long apical hirsute seta (f) and segment $4 \mathrm{~b}$ with one seta (g), shorter than seta $\mathrm{f}$ but reaching beyond the end of the terminal segment. Fifth segment with one apical claw (h2) and one short ventral seta (h1) and one short dorsal seta (h3).

T3 (Fig 7D-E) a cleaning limb with three segments. First segment (protopod) with 3 long setae (d1, $\mathrm{d} 2$ ventrally and dp dorsally); $\mathrm{d} 1$ and $\mathrm{d} 2$ with approximately equal length; dp longer than $\mathrm{d} 1$ and $\mathrm{d} 2$ and reaching higher than distal edge of first endopodal segment. First endopodal segment with ventrosubapical seta e. Terminal endopodal segment with seta $f$ and distal edge as pincer; seta e reaching to half the length of seta $f$ and seta $f$ reaching higher than distal edge of terminal segment. Distal edge of terminal segment with one comb-like seta (h2), one small recurved seta and one longer and distally hirsute seta (h3); seta h2 less than half the length of seta h3; seta h1 not observed.

CR (Fig. 7G) curved and slender (thickening at proximal edge) with ventral side weakly serrated, a proximal and weakly serrated claw, a distal and weakly serrated claw, a proximal hirsute seta and a distal smooth seta. Proximal claw $3 / 4$ of the length of distal claw. Proximal seta about $1 / 3$ of the length of distal seta. 
CR attachment (Fig. 7F) stout, with Triebel's loop in the middle of the distal part of main brand. Distal arc enclosing Triebel's loop thin and acutely connecting to short db, vb well-developed.

\section{Male \\ Unknown. \\ Measurements}

See Table 2.

\section{Remarks}

Following the generic revision by Savatenalinton \& Martens (2009), the present species should be referred to the genus Bradleytriebella, mainly because of the apparent absence of a 'd'-seta on the T1. However, because the position and validity of the S. vinciguerrae/vavrai - group as a whole should be re-assessed, we maintain this species for the time being in Strandesia s.lat.

\section{Discussion}

\section{Taxonomy of Cypricercinae}

The present paper reports on two species of freshwater Ostracoda from Grande Terre, New Caledonia. It provides the re-description of Strandesia sanoamuangae Savatenalinton \& Martens, 2010 and the description of Strandesia mehesi sp. nov. both from female-only populations. This is the second ostracod paper resulting from the "New Caledonia Hydrobiological expeditions 2016-2018", after the description of Cyprinotus drubea by Martens et al. (2019). The current work updates the number of known freshwater Ostracoda of New Caledonia from 14 to 16 species (Table 1), although at least five of these species have an uncertain status.

Strandesia belongs in the subfamily Cypricercinae of the family Cyprididae, together with 11 other genera and its diagnosis here follows that of Savatenalinton \& Martens (2009). However, even after the revisions by Savatenalinton \& Martens $(2009,2010)$, who extracted several species from Strandesia s.lat. and placed them in different, sometimes new, genera, the taxonomy of the genus remains confused. This is so for two main reasons. Firstly, because the genus is speciose (106 extant species worldwide - Meisch et al. 2019) and secondly because very different carapace morphologies are included in it (Ferreira et al. 2020). Whereas the identification of Strandesia sanoamuangae is fairly straightforward, the identity and position of Strandesia mehesi sp. nov. is much more confused.

\section{Strandesia sanoamuangae}

Strandesia sanoamuangae was first described by Savatenalinton \& Martens (2010) from a natural spring in Thailand, and is a very conspicuous species, mainly through the obvious external ornamentation. However, when observing living specimens under a stereo microscope, this ornamentation is less obvious as the species is a very fast swimmer and has striking yellow-green striped patterns. When comparing preserved specimens with SEM-imaging from both areas, however, it is clear that New Caledonian populations resemble the Thai populations strongly in shape and ornamentation of the carapace. Some small differences occur: the specimens from New Caledonia are slightly larger $(\mathrm{L}=888-916 \mu \mathrm{m}$, $\mathrm{n}=2$ ) compared to those from Thailand ( $\mathrm{L}=802-815 \mu \mathrm{m}, \mathrm{n}=2$ ). In addition, the carapace of the New Caledonian specimens is slightly less arched in dorsal and ventral views at their greatest width; its sinuous protrusion in ventral view is slightly anterior to the greatest carapace width; the LV overlap of the RV is slightly narrower, and the overlap of the RV by the LV is inconspicuous at the dorsal margin in right lateral view. We consider these observed differences between the Thai and the New Caledonian specimens to be intraspecific variation. 


\section{Strandesia mehesi sp. nov.}

Strandesia mehesi sp. nov. belongs to a group of small and rounded species within Strandesia s.lat., which we here refer to as the $S$. vinciguerrae/S. vavrai -group, and in which species differ from each other only in details of the valve and the carapace shape and (sometimes) structure (see "differential diagnosis" above). No structural differences were thus far found in the soft parts, but several of the species in this group were described a long time ago (including $S$. vavrai and $S$. vinciguerrae themselves) and few details of limb anatomy and chaetotaxy were described in those days, while of course valves could only be illustrated with drawings as SEM was yet to be invented.

Masi (1905) described Strandesia vinciguerrae from the stomach of a fish on the market of Rome, presumably coming from Lago di Fondi in Italy, but without any illustrations, which is one of the reasons why Müller (1912) listed it as an "uncertain species". Masi (1932) then provided a redescription of the valves in lateral view and of some soft parts of his species, but on two females from the Oasis of El Giof (Cufra Oasis, Libya), not on type specimens, which are presumably lost. Gauthier (1951) provided detailed descriptions and drawings in his re-description of what he identified as $S$. vinciguerrae from Senegal. The specimens described by Gauthier (1951) are more elongated in lateral view than Masi's specimens from Libya, with a smoothly rounded dorsal margin (with a blunt angle in the posterior part in Masi's illustrations) and in addition have the LV considerably overlapping the RV with a wide external flange, even more so than in the present $S$. mehesi sp. nov. Masi (1932) did not illustrate specimens in dorsal or ventral view, so the extend of the LV/RV overlap of his Libyan specimens remains unknown. Based on the original illustrations only, Martens (1984) furthermore sank S. anterotundata Rome, 1977 from Lake Kivu (Rome \& De Deckker 1977) into the synonymy of $S$. vinciguerrae sensu Gauthier, 1951, while Karanovic (2005) placed Strandesia rotunda Hartmann, 1964 into the synonymy of $S$. vinciguerrae, without providing arguments. The latter synonymy was thus rejected by Meisch et al. (2019). Strandesia vinciguerrae has meanwhile been reported by several other authors, most importantly for the present paper by Meisch et al. (2007) from the Pacific Islands Futuna and Wallis. The SEM illustration of a single female carapace in dorsal view (Meisch et al. 2007: fig. 4A) shows the absence of the broad flange on the LV overlapping the RV anteriorly, ventrally and posteriorly, thus clearly showing that this specimen does not belong to $S$. mehesi sp. nov. Beyer et al. (1997: fig $1 \mathrm{~A}-\mathrm{G}$ ) illustrated specimens from the Canary Island (La Gomera) which also lack the flange and LV/ RV overlap and which are also close to Masi's (1932: fig. IIa-b) illustrations of the valves in lateral view. It would thus seem that at least two species, maybe more, have been reported under the name Strandesia vinciguerrae, namely by Masi (1932) and by Gauthier (1951), while it remains unknown if either of these are the true $S$. vinciguerrae as described by Masi (1905). As long as the true identity and morphology of the species $S$. vinciguerrae remains unknown, it will be difficult to unravel to taxonomy of the S. vinciguerrae/S. vavrai species group. New topotype material of this species should be collected and redescribed and a neotype should be designated, but the true type locality (Lago Fondi?) of the species also remains uncertain (see above). In the meantime, we here refrain from identifying our New Caledonian specimens as $S$. vinciguerrae and extensively describe it as a new species as an intermediate step towards a revision of the $S$. vinciguerrae/S. vavrai species group.

Strandesia variegata (Sars, 1901) from Brazil is more elongated, and has the greatest height of the valves well behind the middle (in front of the middle in $S$. mehesi sp. nov.). Karanovic (2005) re-described this species from South Africa, but these specimens are much shorter and higher than the South American specimens, and the presence from this species in South Africa thus remains unconfirmed. Broodbakker (1983) re-investigated the type material of this species and illustrated it as shorter than the original illustrations of Sars (1901), but still more elongated than the South African specimens illustrated by Karanovic (2005). All of these illustrations do show that the greatest height is situated behind the middle, thus the opposite of the situation in S. mehesi sp. nov. from New Caledonia. 
Also S. elliptica (Sars, 1901) described from Brazil and redescribed on the type material by Broodbakker (1983) might belong to this species group, although Higuti et al. (2013) and Ferreira et al. (2020) ranged this species together with $S$. obtusata (Sars, 1901) in another species group in the genus. Broodbakker (1983) illustrated the valves of this species as being more elongated than in Sars's drawings. The shape of the valves is rather similar to those of the New Caledonian species, but the posterior margins of the valves are pointed in the middle in the illustrations of Broodbakker (1983) (these margins are evenly rounded in $S$. mehesi sp. nov.), while Broodbakker also did not indicate the presence of an anterior selvage in the RV. Victor \& Fernando (1981) also illustrated some of these and other species from South East Asia but their (re-) descriptions and illustrations are generally too rudimentary to allow any identification, although their S. mamarilorum sumatrana Victor \& Fernando, 1981 has some resemblance to the new species. Most of the species they (re-) describe will eventually have to be classified as "doubtful species" (following the example of Müller 1912 and the definition in Meisch et al. 2019), especially those originally described by Tressler (1937). Roessler (1990) described Strandesia elliptica mayor Roessler, 1990 from Columbia, but also this (sub-) species does not resemble the New Caledonian species. It is furthermore noteworthy that Bradleystrandesia gr. elliptica (sp. 2, 3, 4) in Higuti et al. $(2007,2009$, 2010) refer to Strandesia lansactohai Higuti \& Martens, 2013, not to S. elliptica itself.

All of the above shows that the $S$. vinciguerrae/S. vavrai species group within Strandesia requires a taxonomic revision, in order to clearly delineate species boundaries and measures of intra specific variability. This will require an integrated taxonomical approach, including molecular analyses as was done for the ellipticalobtusata group from Brazil by Higuti et al. (2013). One of the reasons for this is that we are dealing almost exclusively with fully parthenogenetic lineages, so that the biological species concept cannot apply, as was already foreshadowed by Mayr (1942). A more recent discussion on clonal taxonomy was provided by Martens et al. (2009). It is also quite possible that no congruence will be found between the morphological and molecular species in this species group. Bode et al. (2010) detected ca 40 cryptic genetic species in the classical morphological species Eucypris virens (Jurine, 1820); but Koenders et al. (2016) showed that trees constructed with data from classical valve outline analyses of some of these genetic species were not congruent with the molecular topology, i.e. the molecular species could not be identified based on valve morphology.

\section{Strandesia rouxi Mehés, 1939 and the ostracod material of Méhes (1939)}

Also Strandesia rouxi, described by Méhes (1939) from New Caldedonia itself, somewhat resembles Strandesia mehesi sp. nov. However, the outlines of the valves and carapace as illustrated by Méhes (1939) are not fully congruent with the shape of the new species described here. We thus refrain from identifying the present populations as $S$. rouxi until type materials of this species could be re-investigated. This, however, might not be possible.

Méhes (1939: 549) indicated that his ostracod material from New Caledonia was lodged in the Museum of Basel, where indeed Dr Jean Roux, after whom the species was named, was the curator of invertebrates at that time. The present curator, Dr Eduard Stoeckli, in an e-mail communication (dd. 26 Jun. 2018) kindly checked the collection and confirmed that the Méhes-material is not present in the collections of the Naturhistorisches Museum Basel. Dr Stoeckli also confirmed that Dr Roux died in 1939, i.e. just when the Méhes-paper was published, and this might be the reason that the Méhes-material was never officially entered in the Basel-collection. Earlier enquiries with Dr L. Forro (Natural History Museum of Budapest, Hungary: e-mail dd. 20 Sep. 2016) revealed that the material was collected by Drs Sarasin and Roux in 1911-1912 and was sent to E. Daday (Budapest), but he did not work on it. He gave the material to his student, Gyula Méhes, a high school teacher. This is confirmed by Méhes (1939: 549) himself. Méhes had completed his research in 1914, but was then drafted in the army for the First World War and could not get back to work on the material until the end of the 1930's. 
If indeed the material of Méhes, including the type material of $S$. rouxi, is lost and can no longer be consulted, then it will be best to follow the procedure implemented by Meisch et al. (2019: 110) following Müller (1912) and to catalogue the species $S$. rouxi as "uncertain" or "dubious". At the present stage, we cannot even be certain that the species indeed belongs to Strandesia as Méhes (unaware of the importance of this character at that stage) never illustrated the Triebel's loop in the attachment to the caudal ramus.

\section{Conclusions}

Strandesia sanoamuangae was redescribed and the conspecificity with the original Thai material was confirmed. This is only the second time this species has been reported, and this time from an area, more than $8000 \mathrm{~km}$ from the type locality. It can thus be assumed that this species will also be found in between these two areas.

Strandesia mehesi sp. nov. belongs to a species group in which soft part characters are uniform throughout the group, or unknown in older species where these characters were ignored and where differences in valve shape and structure are also minimal. The New Caledonian specimens are found to show sufficient morphological differences to establish a new species for these populations. However, the whole $S$. vinciguerrae/S. vavrai species group needs to be revised using integrated taxonomy.

The fauna of New Caledonia is rich and generally highly endemic. Further studies on other ostracod species sampled during the three expeditions will allow to also analyse biogeographical patterns, but it is too early for such an attempt. Once the ostracod fauna of the archipelago is better known, however, ostracods could also serve for biomonitoring, while their excellent fossil record might be useful in studying the palaeo-climate of this unique archipelago, a biodiversity hotspot of global conservation importance.

\section{Acknowledgements}

The New Caledonia Hydrobiological expeditions 2016-2018 (PI: Philippe Bouchet, who is here thanked profusely) are part of a cluster of expeditions under the Our Planet Reviewed / La Planète Revisitée programme, implemented by the Muséum National d'Histoire Naturelle (MNHN-HYNC; Pascale Joannot, Head of expeditions programme) in partnership with the Conservatoire d'Espaces Naturels (CEN), with funding from the Gouvernement de la Nouvelle-Calédonie, Province Sud, Province Nord, Office des Postes et Télécommunications (OPT), Maison de la Nouvelle-Calédonie, and the French Ministry for the Overseas. The expeditions operated under permits issued by the Province Sud (under APA_NCPS_2017_028) and Province Nord, and the organizers thank, respectively, Emmanuel Coutures and Isabelle Jurquet (Province Sud) and Jean-Jérôme Cassan and Yannick Monlouis (Province Nord) for their help in the issuance of these permits. For logistics before, during, and after the field work, we thank Sébastien Faninoz, Alice Leblond, Nicolas Charpin and the late Loyola 'Fanfan' Até. Dr E. Stoeckli (Basel, Switserland) and Dr L. Forro (Budapest, Hungary) are thanked for their information on the Méhes ostracod collection. Two anonymous referees suggested improvements. Mr Julien Cillis (Brussels, Belgium) assisted with the Scanning Electron Microscope illustrations. Mrs Laure Corbari (Paris, France) kindly provided registration numbers for the type material of $S$. mehesi sp. nov. Mr Jeroen Venderickx provided assistance with the xml-format of the occurrence data. Dr C. Meisch (Luxembourg) kindly allowed me to use his extensive notes on the literature on non-marine ostracods. The State University of Maringá and the Royal Belgian Institute of natural Sciences (RBINS, Brussels) have a bilateral Memorandum of Understanding regarding collaborative Scientific Research. 


\section{References}

Beauvais M.L., Coléno A. \& Jourdan H. 2006. Synthesis and recommendations. In: Beauvais M.L., Coléno A. \& Jourdan H. (eds) Les espèces envahissantes dans l'archipel néo-calédonien, Invasive Species in the New Caledonian Archipelago: 167-243. Institut de Recherche pour le Développement, Paris.

Beyer G., Meisch C. \& Wouters K. 1997. New records of freshwater Ostracoda (Crustacea) from La Gomera, El Hierro, Fuertoventura and Tenerife (Canary Islands). Bulletin de la Société des naturalistes Luxembourgeoise 98: 239-259.

Bode S.N.S., Adolfsson S., Lamatsch D.K., Martins M.J.F., Schmit O., Vandekerkhove J., Mezquita F., Namiotko T., Rossetti G., Schön I., Butlin R.K. \& Martens K. 2010. Exceptional cryptic diversity and multiple origins of parthenogenesis in a freshwater ostracod. Molecular Phylogenetics and Evolution 54: 542-552. https://doi.org/10.1016/j.ympev.2009.08.022

Boomer I., Horne D.J. \& Slipper I.J. 2003. The use of ostracods in palaeoenvironmental studies, or what can you do with an ostracod shell? The Paleontological Society Papers 9: 153-180.

https://doi.org/10.1017/S1089332600002199

Brady G.S. 1890. On Ostracoda collected by H.B. Brady, Esq., L.L.D., F.R.S, in the South Sea Islands. Transactions of the Royal Society of Edinburgh 25:489-525 https://doi.org/10.1017/S0080456800017749

Broodbakker N.W. 1983. The genus Strandesia and other Cypricercini (Crustacea, Ostracoda) in the West Indies. Part I. Taxonomy. Bijdragen tot de Dierkunde 53: 327-368.

https://doi.org/10.1163/26660644-05302012

Broodbakker N.W. \& Danielopol D.L. 1982. The chaetotaxy of Cypridacea (Crustacea, Ostracoda) Limbs: Proposals for a descriptive model. Bijdragen tot de Dierkunde 52: 103-120.

https://doi.org/10.1163/26660644-05202003

Caesar M., Grandcolas P. \& Pellens R. 2017. Outstanding micro-endemism in New Caledonia: more than one out of ten animal species have a very restricted distribution range. PLOS ONE 12: e0181437. https://doi.org/10.1371/journal.pone.0181437

Danielopol D.L., Ito E., Wansard G., Kamiya T., Cronin T.M. \& Baltanas A. 2002. Techniques for collection and study of Ostracoda. In: Holmes A.J. \& Chivas A.R. (eds) The Ostracoda: applications in Quaternary research.AGU Geophysical Monograph Series 131: 5-36. https://doi.org/10.1029/131GM04

De Deckker P. 1979. Comparative morphology and review of Australian Notodromatinae Kaufmann, 1900 (Crustacea, Ostracoda). Senckenbergiana biologica 59: 417-463.

De Deckker P. 1981. Ostracoda from Australian inland waters - notes on taxonomy and ecology. Proceedings of the Royal Society of Victoria 93: 43-85.

Ferreira V.G., Higuti J. \& Martens K. 2019. A striking case of convergent evolution in two species of Cypricercinae (Crustacea, Ostracoda), with the description of a new genus and species from Brazil. Zoologischer Anzeiger 283: 1-11. https://doi.org/10.1016/j.jcz.2019.06.007

Ferreira V.G., Higuti J. \& Martens K. 2020. Taxonomic revision of Strandesia s.s. (Crustacea, Ostracoda) from four Brazilian floodplains, with the description of three new species. Zootaxa.

https://doi.org/10.11646/zootaxa.4760.1.1

Gauthier H. 1951. Contribution à l'étude de la faune des eaux douces au Sénégal (Entomostracés). Minerva, Algiers. 
Grandcolas P. 2017. Ten false ideas about New Caledonia biogeography. Cladistics 33: 481-487. https://doi.org/10.1111/cla.12176

Harter D.E.V., Irl S.D.H., Seo B., Steinbauer M.J., Gillespie R., Triantis K.A., Fernández-Palacios J.M. \& Beierkuhnlein C. 2015. Impact of global climate change on the floras of oceanic islands - projections, implications and current knowledge. Perspectives in Plant Ecology, Evolution and Systematics 17: 160183. https://doi.org/10.1016/j.ppees.2015.01.003

Higuti J., Velho L.F.M., Lansac-Tôha F.A. \& Martens K. 2007. Pleuston communities are buffered from regional flood pulses: the example of ostracods in the Paraná River floodplain, Brazil. Freshwater Biology 52: 1930-1943. https://doi.org/10.1111/j.1365-2427.2007.01821.x

Higuti J., Velho L.F.M., Lansac Tôha F.A \& Martens K. 2009. Biodiversity of non-marine ostracods (Crustacea, Ostracoda), in the alluvial valley of the upper Paraná River, Brazil. Brazilian Journal of Biology 69 (suppl.): 661-668. https://doi.org/10.1590/S1519-69842009000300020

Higuti J., Declerck S.A.J., Lansac-Tôha F.A., Velho L.F.M. \& Martens K. 2010. Variation in ostracod (Crustacea, Ostracoda) communities in the alluvial valley of the upper Paraná River (Brazil) in relation to substrate. Hydrobiologia 644: 261-278. https://doi.org/10.1007/s10750-010-0122-1

Higuti J., Schön I., Audenaert L. \& Martens K. 2013. On the Strandesia obtusatalelliptica - lineage (Ostracoda, Cyprididae) in the alluvial valley of the Upper Paraná River (Brazil), with the description of three new species. Crustaceana 86: 182-211. https://doi.org/10.1163/15685403-00003160

Hoibian T., Ayress M. \& Allenbach M. 2000. Ostracod (Crustacea) populations as environmental indicators of inter-tropical transitional deltaic environments. An example from the Néru Delta, NewCaledonia, South-West Pacific. Revue de Paléobiologie 19: 207-225.

Hoibian T., Ayress M. \& Allenbach M. 2002. Ostracod assemblages of Roche Percée bay and adjacent fringing reef-flats - New Caledonia - South-west Pacific. Revue de Paléobiologie 21: 177-191.

Horne D.J., Cohen A. \& Martens K. 2002. Taxonomy, morphology and biology of Quaternary and living Ostracoda. In: Holmes A.J. \& Chivas A.R. (eds) The Ostracoda: applications in Quaternary research: 5-36. AGU Geophysical Monograph Series 131. https://doi.org/10.1029/131GM02

Karanovic I. 2005. On the genus Strandesia Stuhlmann, 1888 (Crustacea, Ostracoda, Cyprididae) with the description of Strandesia kimberleyensis n.sp. and a key to the extant species of the genus. Contributions to Zoology 774: 79-97. https://doi.org/10.1163/18759866-0740102006

Koenders A., Schön I., Halse S. \& Martens K. 2016. Valve shape is not linked to genetic species in the Eucypris virens (Ostracoda, Crustacea) species complex. Zoological Journal of the Linnean Society 180: $36-46$ https://doi.org/10.1111/zoj.12488

Maddocks R. 2007. Podocopid and Platycopid Ostracoda of New Caledonia. In: Payri C.E. \& Richter de Forges B. (eds.) Compendium of marine species of New Caledonia: 269-273 Documents Scientifiques et techniques II7, IRD, Nouméa.

Martens, K. 1984. Annotated checklist of non-marine ostracods (Ostracoda, Crustacea) from African inland waters. Zoologische Bijdragen van het koninklijk Museum voor Midden Afrika, Tervuren 20: $1-51$.

Martens K. 1987. Homology and functional morphology of sexual dimorphism in the antenna of Sclerocypris Sars, 1924 (Crustacea, Ostracoda, Megalocypridinae). Bijdragen tot de Dierkunde 57: 183-190. https://doi.org/10.1163/26660644-05702003 
Martens K. \& Rossetti G. 2002. On the Darwinulidae (Crustacea, Ostracoda) from Oceania, with the description of Vestalenula matildae. Invertebrate Systematics 16:195-208.

https://doi.org/10.1071/IT01022

Martens K., Schön I., Meisch C. \& Horne D.J. 2008. Global diversity of ostracods (Ostracoda, Crustacea) in freshwater. Hydrobiologia 595: 185-193. https://doi.org/10.1007/s10750-007-9245-4

Martens K. \& Horne D.J. 2009. Ostracoda. In: Likens G.E. (ed) Encyclopedia of Inland Waters. Elsevier Publishers 405-414. https://doi.org/10.1016/B978-012370626-3.00184-8

Martens K., Loxdale H. \& Schön I. 2009. The Elusive Clone - In Search of Its True Nature and Identity. In: Schön I., Van Dijk P. \& Martens K. (eds.) Lost Sex. Springer: 187-200.

https://doi.org/10.1007/978-90-481-2770-2_9

Martens K. \& Horne D.J. 2016. Collecting and processing living non-marine ostracods. Journal of Crustacean Biology 36: 849-854. https://doi.org/10.1163/1937240X-00002488

Martens K., Yavuzatmaca M. \& Higuti J. 2019. On a new species of the genus Cyprinotus (Crustacea, Ostracoda) from a temporary wetland in New Caledonia (Pacific Ocean), with a reappraisal of the genus. European Journal of Taxonomy 566: 1-22. https://doi.org/10.5852/ejt.2019.566

Masi, L. 1905. Nota sopra una nuova specie di Cypris sessuata e sulla Cypris bispinosa. Monitore zoologico Italiano $16: 240-244$.

Masi, L. 1932. Spedizione Scientifica all' Oasi di Cufra. (Mauzo-Luglio, 1931). Ostracodi. Annali del Museo Civico Di Storia Naturale Di Genova 55: 1-19.

Mayr E. 1942. Systematics and the Origin of Species, from the Viewpoint of a Zoologist. Harvard University Press, Cambridge.

Méhes G. 1939. Ostracodes de la Nouvelle-Caledonie. Revue Suisse de Zoologie 46: 549-566.

Meisch C. 2000. Freshwater Ostracoda of Western and Central Europe. Spektrum Akademischer Verlag GmbH. Heidelberg.

Meisch C., Mary-Sasal N., Colin J.P. \& Wouters K. 2007. Freshwater Ostracoda (Crustacea) collected from the islands of Futuna and Wallis, Pacific Ocean, with a checklist of the non-marine Ostracoda of the Pacific Islands. Bulletin de la Societé des naturalistes luxembourgeois 108: 89-103.

Meisch C., Smith R. \& Martens K. 2019. A subjective global checklist (submitted) of the Recent non-marine Ostracoda (Crustacea). European Journal of Taxonomy 492:1-135.

https://doi.org/10.5852/ejt.2019.492

Mortimer N., Campbell H.J., Tulloch A.J., King P.R., Stagpoole V., Wood R.A., Rattenbury M.S., Sutherland R., Adams C.J., Collot J. \& Seton M. 2016. Zealandia: earth's hidden continent. GSA Today 27: 27-35. https://doi.org/10.1130/GSATG321A.1

Müller G.W. 1898. Wissenschaftlichen Ergebnisse der Reisen in Madagaskar und Ostafrika in den Jahren 1889-95 von Dr A. Voeltzkow. Die Ostracoden. Abhandlungen der Senckenbergischen naturforschenden Geselschaft 21 (2): 255-296.

Müller G.W. 1906. Ostracoden aus Java, gesammelt von Prof. K. Kraepelin. Mitteilungen aus dem Naturhistorischen Museum in Hamburg 23: 139-142.

Müller G.W. 1912. Ostracoda. In: Schulze F.E. (ed.) Das Tierreich 31. Friedlander \& Sohn, Berlin. 
Murienne J. 2009. New Caledonia Biology. In: Gillespie R.G. \& Clague D.A. (eds) Encyclopedia of Islands: 643-645. University of California Press, Berkeley, CA.

Myers N., Mittermeier R.A., Mittermeier C.G., Da Fonseca G.A.B. \& Kent J. 2000. Biodiversity hotspots for conservation priorities. Nature 403: 853-858. https://doi.org/10.1038/35002501

Nattier R., Pellens R., Robillard T., Jourdan H., Legendre F., Caesar M., Nel A. \& Grandcolas P. 2017. Updating the phylogenetic dating of New Caledonian biodiversity with a meta-analysis of the available evidence. Science Reports 7: 3705. https://doi.org/10.1038/s41598-017-02964-x

Neale J. 1979. On the genus Cyprinotus and its interpretation. Proceedings of the VII International Symposium on ostracodes. Taxonomy, Biostratigraphy and Distribution of ostracodes. Serbian Geological Society, Belgrade: 77-85.

Pouteau R. \& Birnbaum P. 2016. Island biodiversity hotspots are getting hotter: vulnerability of tree species to climate change in New Caledonia. Biological Conservation 201:111-119.

https://doi.org/10.1016/j.biocon.2016.06.031

Rawling T.J. 2009. New Caledonia Geology. In: Gillespie R.G. \& Clague D.A. (eds) Encyclopedia of Islands: 645-648. University of California Press, Berkeley, CA.

Rome D.R. \& De Deckker P. 1977. Ostracodes du Lac Kivu. Mémoires de l'Institut géologique de l'Université de Louvain 29 : 241-287.

Roessler E.W. 1990. Estudios taxonómicos, ontogene'ticos, ecolo'gicos y etolo'gicos sobre los ostracodos de agua dulce en Colombia (Ostracoda, Podocopida, Cyprididae) - 6: Estudio taxonómico del género Strandesia Stuhlmann, 1888 - Parte 3: El grupo 'Strandesia elliptica (Sars, 1901)'. Revista de la Academia Colombiana de Ciencias Exactas, Físicas y Naturales 17: 795-804.

Rossetti G. \& Martens K. 1999. Contribution to taxonomy and distribution of the genus Vestalenula Rossetti \& Martens, 1998 (Crustacea. Ostracoda, Darwinulidae), with the description of two new species. Bulletin de I'Institut Royal des Sciences Naturelles de Belgique, Biologie 69: 57-66.

Ruiz F., Abad M., Bodergat A.M., Carbonel P., Rodríguez-Lázaro J., González-Regalado M.L., Toscano A., García E.X. \& Prenda J. 2013. Freshwater ostracods as environmental tracers. International Journal of Environmental Science and Technology 10: 1115-1128. https://doi.org/10.1007/s13762-013-0249-5

Sars G.O. 1901. Contributions to the knowledge of the fresh-water Entomostraca of South America as shown by artificial hatching from dried material. Part II. Copepoda-Ostracoda. Archiv for Mathematik og Naturvidenskab B. XXIV: 3-52.

Savatenalinton S. \& Martens K. 2009. Generic revision of Cypricercinae Mckenzie, 1971 (Crustacea, Ostracoda), with the description of three new genera and one new species and a phylogenetic analysis if the subfamily. Hydrobiologia 632: 1-48. https://doi.org/10.1007/s10750-009-9826-5

Savatenalinton S. \& Martens K. 2010. On the subfamily Cypricercinae McKenzie, 1971 (Crustacea, Ostracoda) from Thailand, with the description of six new species. Zootaxa 2379: 1-77.

https://doi.org/10.11646/zootaxa.2379.1.1

Schabetsberger R., Drozdowski G., Rott E., Lenzenweger R., Jersabek C.D., Stoch F., Kotov A.A., Martens K., Reiff N., Traunspurger W. \& Schatz H. 2009. Loosing The Bounty? Investigating Species Richness In Isolated Freshwater Ecosystems Of Oceania. Pacific Science 63 (2):153-179.

https://doi.org/10.2984/049.063.0201 
Tressler W. L. 1937. Ostracoda. In: Mitteilungen 18 von der Wallacea Expedition. Internationale Revue der gesamten Hydrobiologie und Hydrographie 34: 188-207. https://doi.org/10.1002/iroh.19370340112

Victor R. \& Fernando H. 1981. Freshwater Ostracods (Crustacea: Ostracoda) of the genus Strandesia VAVRA, 1895 from Malaysia, Indonesia and the Philippines. Archiv für Hydrobiologie, Supplementbände (Monographische Beiträge) 58 (4) 469-522.

Manuscript received: 16 August 2019

Manuscript accepted: 19 November 2019

Published on: 15 April 2020

Topic editors: Rudy Jocqué and Gavin Broad

Desk editor: Jeroen Venderickx

Printed versions of all papers are also deposited in the libraries of the institutes that are members of the EJT consortium: Muséum national d'Histoire naturelle, Paris, France; Meise Botanic Garden, Belgium; Royal Museum for Central Africa, Tervuren, Belgium; Royal Belgian Institute of Natural Sciences, Brussels, Belgium; Natural History Museum of Denmark, Copenhagen, Denmark; Naturalis Biodiversity Center, Leiden, the Netherlands; Museo Nacional de Ciencias Naturales-CSIC, Madrid, Spain; Real Jardín Botánico de Madrid CSIC, Spain; Zoological Research Museum Alexander Koenig, Bonn, Germany; National Museum, Prague, Czech Republic. 